\title{
Geologic Framework and Hydrogeology of the Rio Rico and Nogales 7.5' Quadrangles, Upper Santa Cruz Basin, Arizona, with Three-Dimensional Hydrogeologic Model
}

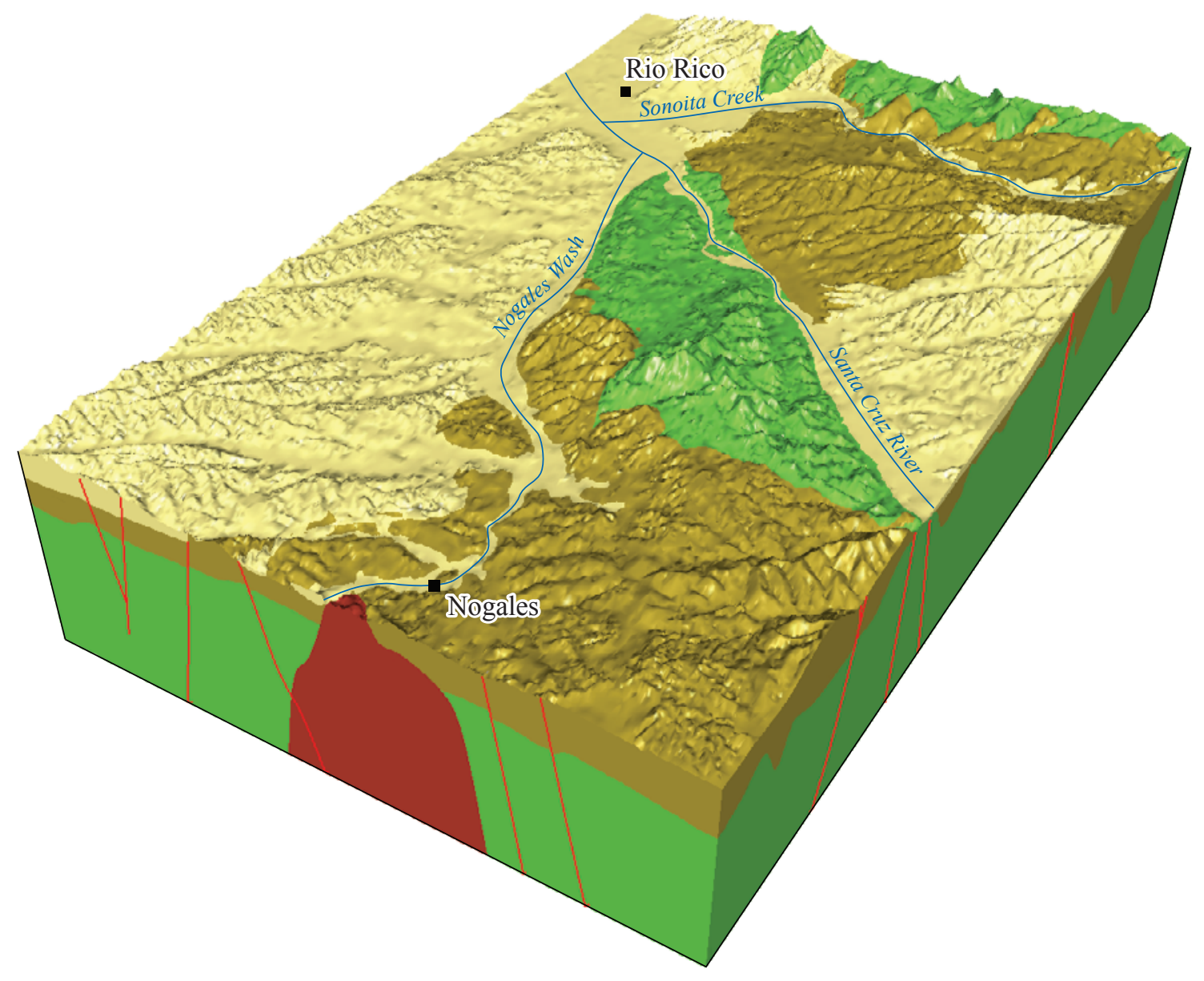

Scientific Investigations Report 2018-5062 
Cover. View to the northwest of the three-dimensional hydrogeologic model, showing the distribution of hydrogeologic units. 


\section{Geologic Framework and Hydrogeology of the Rio Rico and Nogales 7.5' Quadrangles, Upper Santa Cruz Basin, Arizona, with Three-Dimensional Hydrogeologic Model}

By William R. Page, Mark W. Bultman, D. Paco VanSistine, Christopher M. Menges, Floyd, Gray, and Michael P. Pantea

Scientific Investigations Report 2018-5062 


\title{
U.S. Department of the Interior \\ RYAN K. ZINKE, Secretary
}

\author{
U.S. Geological Survey \\ James F. Reilly II, Director
}

U.S. Geological Survey, Reston, Virginia: 2018

For more information on the USGS - the Federal source for science about the Earth, its natural and living resources, natural hazards, and the environment-visit https://www.usgs.gov or call 1-888-ASK-USGS.

For an overview of USGS information products, including maps, imagery, and publications,

visit https://store.usgs.gov.

Any use of trade, firm, or product names is for descriptive purposes only and does not imply endorsement by the U.S. Government.

Although this information product, for the most part, is in the public domain, it also may contain copyrighted materials as noted in the text. Permission to reproduce copyrighted items must be secured from the copyright owner.

Suggested citation:

Page, W.R., Bultman, M.W., VanSistine, D.P., Menges, C.M., Gray, Floyd, and Pantea, M.P., 2018, Geologic framework and hydrogeology of the Rio Rico and Nogales 7.5' quadrangles, upper Santa Cruz Basin, Arizona, with threedimensional hydrogeologic model: U.S. Geological Survey Scientific Investigations Report 2018-5062, 34 p., https://doi.org/10.3133/sir20185062.

ISSN 2328-0328 (online) 


\section{Contents}

Abstract

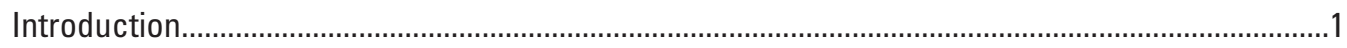

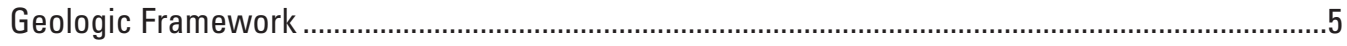

3D Model Hydrogeologic Units .........................................................................................

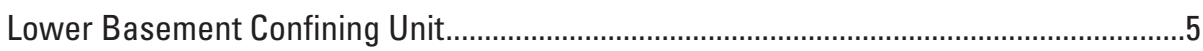

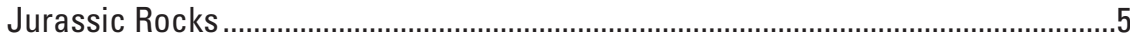

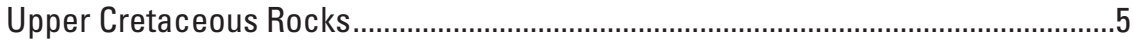

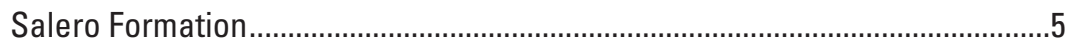

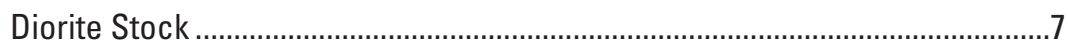

Tertiary Volcanic and Plutonic Rocks ....................................................................

Oligocene Grosvenor Hills Volcanics ................................................................

Middle Unit Consisting of the Miocene Nogales Formation...............................................11

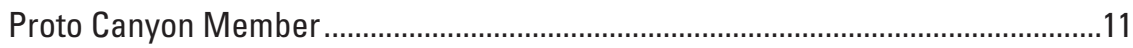

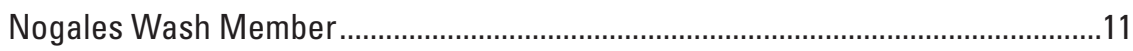

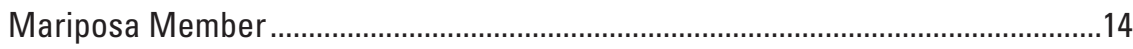

Hydraulic Properties and Hydrogeologic Characteristics of the Miocene

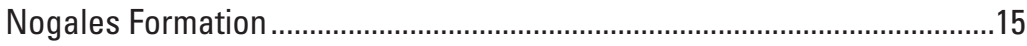

Upper Hydrogeologic Unit Consisting of Late Miocene to Early Pleistocene

Basin-Fill Deposits, and Early Pleistocene to Holocene Alluvium, Combined ...16

Late Miocene to Early Pleistocene Basin-Fill Deposits ........................................17

Early Pleistocene to Holocene Alluvium ....................................................................19

Hydraulic Properties of Late Miocene to Early Pleistocene Basin-Fill

Deposits, and Early Pleistocene to Holocene Alluvium .................................20

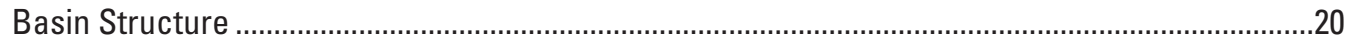

Miocene to Holocene Development of the Upper Santa Cruz Basin in the Study Area ..................24

Data for Construction of the Three-Dimensional Hydrogeologic Model.........................................26

Geologic Map, Cross Sections, and Digital Elevation Data ....................................................26

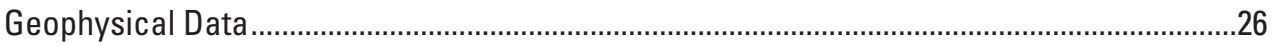

Depth to Basement Map.................................................................................................28

Mapping Concealed Faults and Contacts......................................................................28

Water Well Data

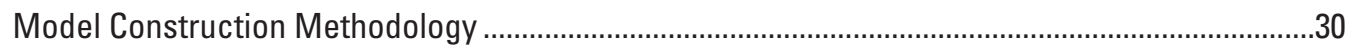

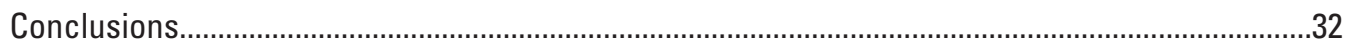

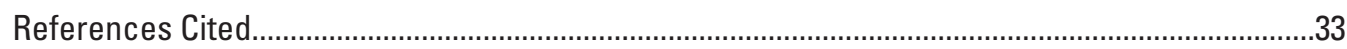




\section{Figures}

1. Location map of upper Santa Cruz Basin area, Arizona, showing major physiographic, geologic, and hydrologic features in the region

2. Location map of study area which extends over the Rio Rico and Nogales 7.5' quadrangles, Arizona, showing major physiographic, geologic, and hydrologic features in the area

3. Three-dimensional model block diagram showing geologic map of the Rio Rico and Nogales 7.5' quadrangles, Arizona, draped over digital elevation model.

4. Statigraphic chart of the geologic units in the Rio Rico and Nogales 7.5' quadrangles, Arizona .

5. Three-dimensional model block diagram oblique view to northwest showing the distribution of hydrogeologic units.

6. Three-dimensional model block diagram oblique view to southeast showing the complex and faulted top surface of the basement confining unit, which was modeled based on a combination of geologic map and cross section data from Page and others (2016b) and geophysical data (Bultman and Page, 2016)

7. Three-dimensional model block diagram oblique view to northwest, showing location of the Mount Benedict horst block at the surface, in relation to the modeled hydrogeologic units

8. Photograph showing view to the north of Quartz Monzonite of Mount Benedict south of Mount Benedict.

9. Photograph showing outcrops of the Salero Formation along Santa Cruz River, south of Sonoita Creek and north of Guevavi Canyon.

10. A, three-dimensional model block diagram oblique view to the northeast showing the middle hydrogeologic unit of the Nogales Formation overlying basement. $B$, oblique view to the northwest showing the middle hydrogeologic unit of the Nogales Formation above the basement confining unit, including the Upper Cretaceous diorite stock

11. Photograph showing red and white gravelly claystone and overlying gray tuffaceous sandstone beds in the middle part of the Proto Canyon member in Yerba Buena Canyon.

12. Photograph showing pinkish-gray, moderately consolidated volcaniclastic sandstone in the uppermost part of the Proto Canyon member, between Interstate 19 and Grand Avenue, and north of Mariposa Road...

13. Photograph showing massive, cliff-forming, moderately consolidated volcaniclastic sandstone and conglomeritic sandstone in the basal part of the Nogales Wash member along Grand Avenue, south of Mariposa Road.

14. Photograph showing faulted and highly rotated beds (dipping $48^{\circ}$ northwest) of Mariposa member in Interstate 19 area, north of Mariposa Road; beds consist of moderately sorted volcaniclastic conglomeritic sandstone, sandstone, and minor siltstone.

15. Photograph showing massive claystone unit in the Mariposa member on south side of Mariposa Road, between Grand Avenue and Interstate 19.

16. Photograph showing subvertical fractures in Mariposa member in roadcut along Interstate 19, north of Mariposa Road; roadcut about 7 meters in height.

17. Photograph showing north view of intersecting fractures (accented by linear vegetation patterns) in volcaniclastic sandstone units in the Nogales Formation in the Agua Fria Canyon area 
18. A, three-dimensional model block diagram oblique view to the southeast of upper hydrogeologic unit. Unit thickness is interpreted to increase to maximum thicknesses of about 150 meters in the Rio Rico area, at northwestern model edge. $B$, oblique view to the northeast of the upper hydrogeologic unit.

19. Photograph showing $A$, view to the east of reddish-brown late Miocene to early Pleistocene basin-fill deposits (QTa) unconformably overlying Nogales Wash member of the Nogales Formation (Tnn) in a roadcut at Crawford Hill. $B$, view to the west directly across Interstate 10 from roadcut at Crawford Hill, showing subvertical fault juxtaposing sediments of the Nogales Wash Member of Nogales Formation (Tnn) in footwall, against late Miocene to early Pleistocene basin-fill deposits (QTa) in hanging wall.

20. Three-dimensional model block diagram of geologic map of Page and others (2016b) draped over digital elevation model, showing major faults and a complex graben.

21. Three-dimensional model block diagram oblique southeast view of top of basement surface showing Mount Benedict horst block separating this part of the upper Santa Cruz basin into two groundwater basins, one to the east (East basin), and the other to the west (West basin) of the horst block .

22. Diagrammatic east-west oriented cross sections across the Mount Benedict horst block, showing the sequential development of the southern upper Santa Cruz Basin from early Miocene to present. $A$, deposition of late Miocene to Holocene surficial deposits above exhumed and deformed Nogales Formation sediments. $B$, middle to late Miocene deposition of the Mariposa member of the Nogales Formation. $C$, middle Miocene deposition of the Nogales Wash member of the Nogales Formation. $D$, early Miocene deposition of the Proto Canyon member of the Nogales Formation, including debris-flow conglomerate shed off flanks of Mount Benedict horst block

23. Depth to basement map of Bultman and Page (2016) showing six interpreted subbasins in the 3D-model area.

24. Three-dimensional model block diagram oblique view northwest view showing basement surface and subbasins labeled in figure 23 .

25. Three-dimensional model block diagram oblique view to the north along the southern model edge showing $X, Y$, and Z coordinates for groundwater elevation data 


\section{Conversion Factors}

International System of Units to U.S. customary units

\begin{tabular}{lll}
\hline \multicolumn{1}{c}{ Multiply } & \multicolumn{1}{c}{ By } & \multicolumn{1}{c}{ To obtain } \\
\hline & Length & \\
\hline centimeter $(\mathrm{cm})$ & 0.3937 & inch (in.) \\
meter $(\mathrm{m})$ & 3.281 & foot (ft) \\
meter $(\mathrm{m})$ & 1.094 & yard (yd) \\
kilometer $(\mathrm{km})$ & 0.6214 & mile (mi) \\
\hline
\end{tabular}

\section{Datum}

Vertical coordinate information is referenced to the North American Vertical Datum of 1988 (NAVD 88).

Horizontal coordinate information is referenced to the North American Datum of 1983 (NAD 83).

Altitude, as used in this report, refers to distance above the vertical datum. 


\title{
Geologic Framework and Hydrogeology of the Rio Rico and Nogales 7.5' Quadrangles, Upper Santa Cruz Basin, Arizona, with Three-Dimensional Hydrogeologic Model
}

\author{
By William R. Page, Mark W. Bultman, D. Paco VanSistine, Christopher M. Menges, Floyd Gray, and \\ Michael P. Pantea
}

\begin{abstract}
Rapid population growth and declining annual recharge to aquifers in the upper Santa Cruz Basin area of southern Arizona, have increased the demand for additional groundwater resources. This demand is predicted to escalate in the future because of higher temperatures, longer droughts, less aquifer recharge, and decreased river and stream base flow. We conducted geologic studies to help evaluate and better understand groundwater resources in the basin. Results of these studies are presented in this report, which summarizes the basin geologic framework and hydrogeology, and presents a threedimensional (3D) hydrogeologic model for the Rio Rico and Nogales 7.5' quadrangles. Three major hydrogeologic units are displayed in the 3D model; a lower basement confining unit, consisting of Jurassic, Cretaceous, and Tertiary (Paleocene and Oligocene) rocks; a middle unit composed entirely of the Miocene Nogales Formation; and an upper unit consisting of late Miocene to Holocene surficial deposits. The Nogales Formation and the late Miocene to Holocene sediments are the main aquifers in the upper Santa Cruz Basin. The 3D model integrates the hydrogeologic units and faults to define the geometry, structure, and thickness of the aquifer system that provides water to Nogales and surrounding communities of southernmost Arizona. The report includes an EarthVision 3D Viewer, consisting of software enabling the user to view data interactively in 3D space to help explain the internal complexities of the basin geometry, structure, stratigraphy, and hydrology. The 3D model is a synthesis of geologic data from geologic maps, cross sections, and lithologic descriptions and interpretations; and geophysical data including gravity, magnetic data, and airborne electromagnetic data.
\end{abstract}

\section{Introduction}

The report summarizes the geologic framework and hydrogeology in the Rio Rico and Nogales 7.5' quadrangles, southern Arizona (figs. 1 and 2), and presents a three dimensional (3D) hydrogeologic model for the area. The main objective in preparing the $3 \mathrm{D}$ model is to investigate groundwater resources in the upper Santa Cruz Basin, but the model may also be important in addressing U.S.-Mexico border security issues, including conducting investigations to evaluate the geologic and geophysical framework in detecting and (or) predicting the location of tunnels beneath the border.

The 3D model was constructed using EarthVision (Dynamic Graphics, Inc., http://www.dgi.com), a 3D modeling software package used for analysis, synthesis, modeling, and visualization of geoscience data. A principal component of this report is a 3D Viewer, which consists of software enabling the user to view data interactively in $3 \mathrm{D}$ space, and the ability to sequentially slice through and rotate the modeled geology, to help explain the internal complexities of the basin. The 3D Viewer and related files are accessed from Page (2018), which is the U.S. Geological Survey data release for the 3D model, and may be found at http://doi.org/10.5066/F7QJ7GHT; documentation for use of the 3D Viewer is available at this link by opening the file "Demo_3D_Viewer.pdf." Although the model was constructed using EarthVision software, the 3D Viewer is a limited functionality version of the EarthVision main modeling program, that allows interactive visualization and manipulation of 3D models using encrypted faces files. Once the encrypted file for the model is loaded on a computer, scattered data and image registration files can be loaded and displayed for model analyses. Scattered datasets (EarthVision .dat file format) in the report include (1) files of all modeled fault sheet surfaces, (2) files defining the surfaces of the Upper Cretaceous diorite stock at the southern edge of the model, and (3) groundwater elevation data points recorded from shallow water wells in the area. Image registration files include selected airborne electromagnetic data in the form of Conductivity Depth Transforms (CDTs) in the 3D-model area.

Geologic units in the study area range in age from Jurassic through Holocene, and are defined and modified for the 3D model, primarily from the geologic map of Page and others (2016b; https://doi.org/10.3133/sim3354). The geologic map file (EarthVision imreg file format) can be loaded and displayed in the 3D Viewer, and figure 3 is a graphic representation of the map draped over the digital elevation model (DEM), showing labeled major geologic units and faults. 


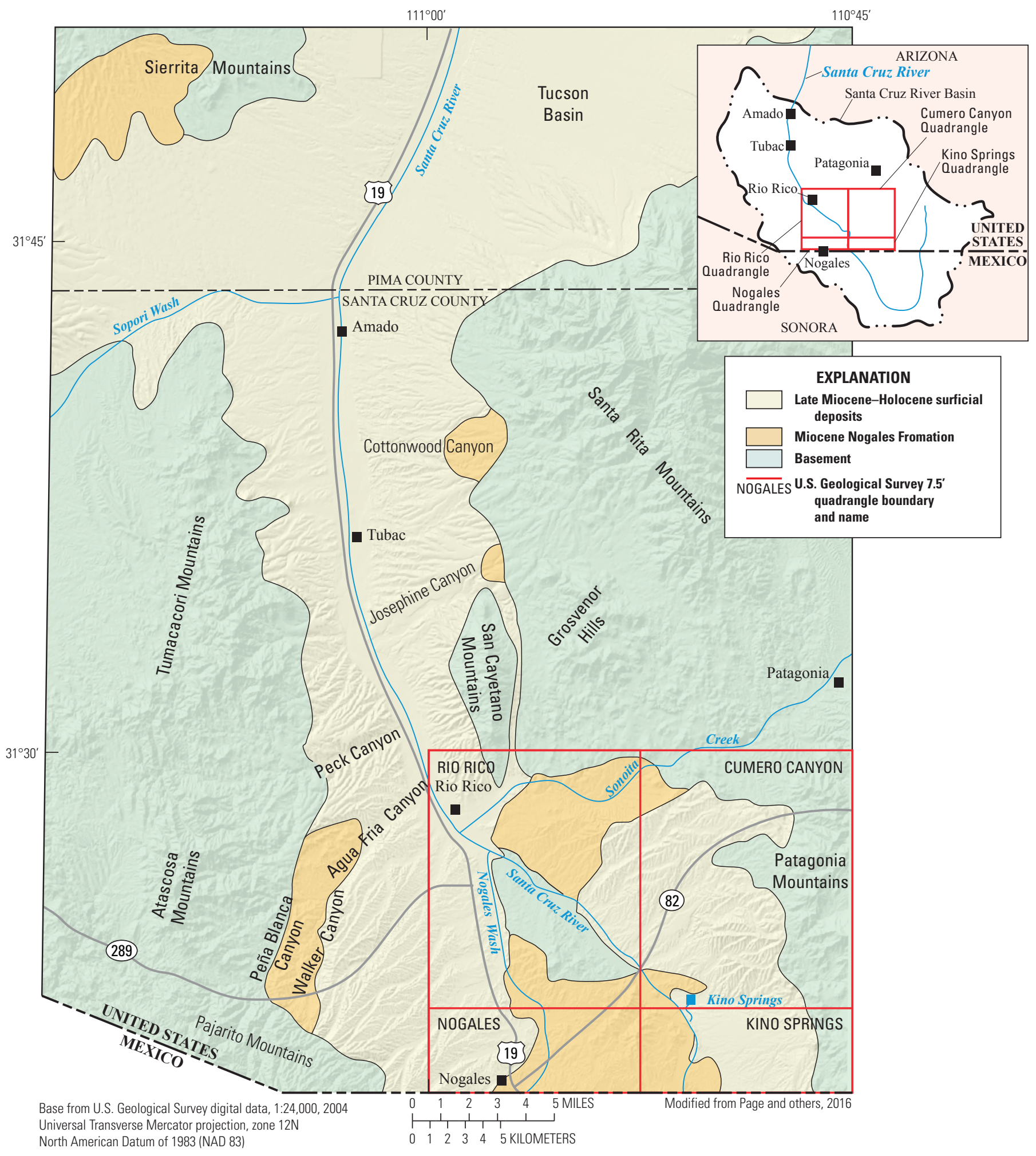

Figure 1. Upper Santa Cruz Basin area, Arizona, showing major physiographic, geologic, and hydrologic features in the region. 


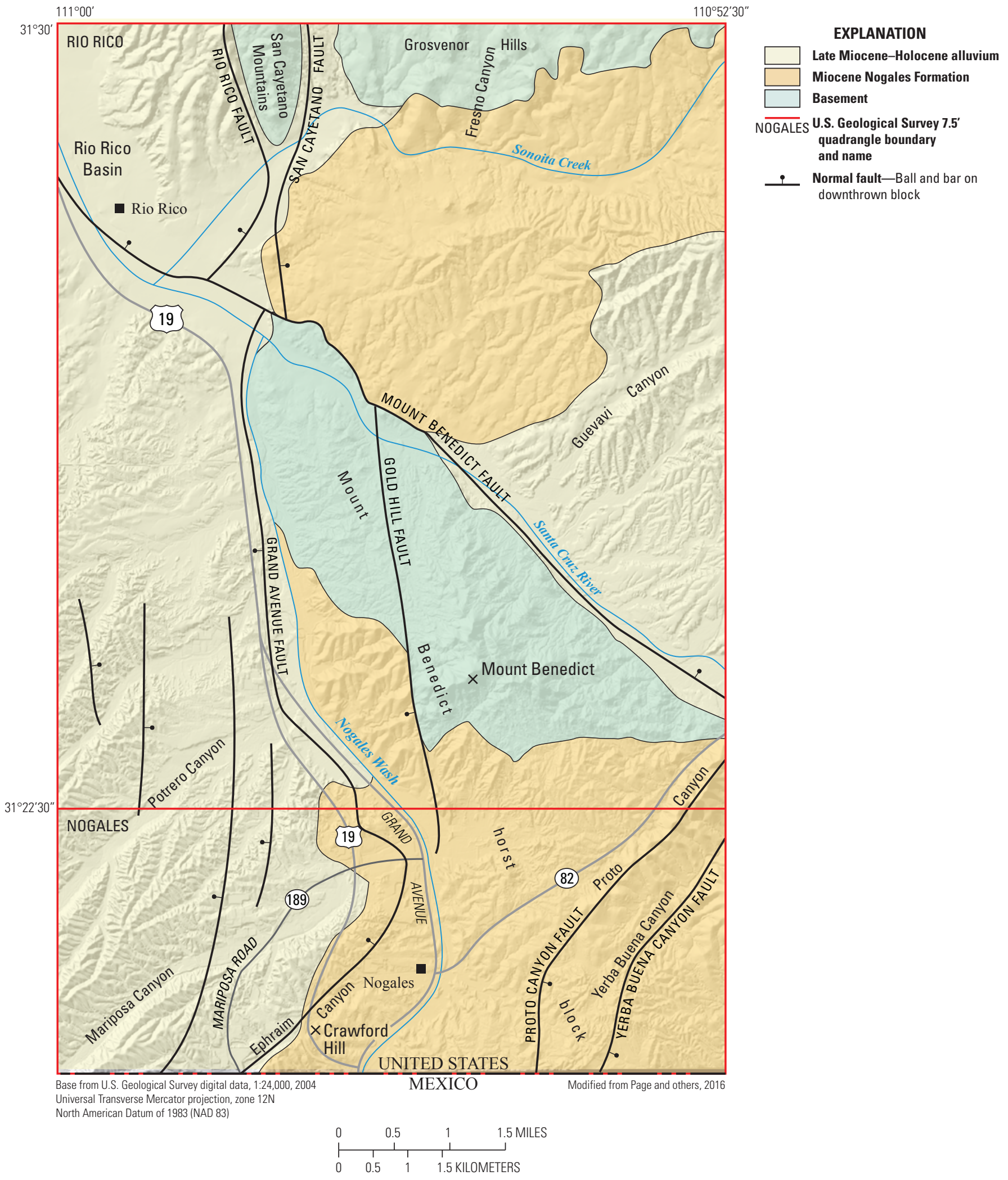

Figure 2. Study area which extends over the Rio Rico and Nogales 7.5' quadrangles, Arizona, showing major physiographic, geologic, and hydrologic features in the area. 


\title{
EXPLANATION
}

QTa Late Miocene to Holocene surficial deposits

Nogales Formation (Miocene)

Tnm Mariposa member

Tnn Nogales Wash member

Tnp Proto Canyon member

ETg-Grosvenor Hills Volcanics (Oligocene)

Diorite stock (Upper Cretaceous)

Ks Salero Formation (Upper Cretaceous)

Quartz Monzonite of Mount Benedict (Jurassic)

$\mathrm{Jb}$ Biotite-hornblende quartz monzonite

Jbm Quartz monzonite

Upper hydrogeologic unit

Late Miocene to Holocene surficial deposits

Middle hydrogeologic unit

Miocene Nogales Formation

Lower hydrogeologic unit

Jurassic, Cretaceous, and Tertiary (Oligocene) rocks

? Normal fault-Ball and bar on downthrow block

Fault where projects out of model area

\author{
urassic)
}

(1)

Hat

I

$1 \mathrm{~N}$ QTa

METERS
1.500

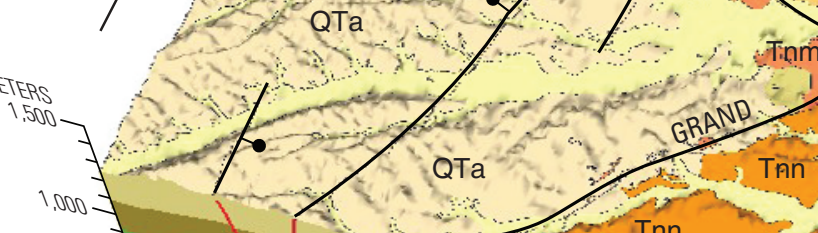

$+1,20$

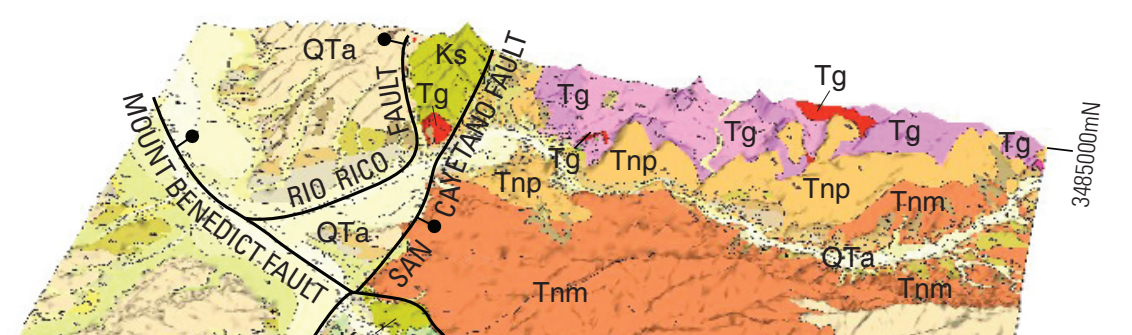

.


Figure 4 lists and describes the geologic units, which are combined from Page and others (2016b), to form three major hydrogeologic units in the model. Figure 5 shows the distribution of the lower, middle, and upper hydrogeologic units in the 3D model. A basement confining unit makes up the lower unit; these rocks form the majority of the model volume and consist of Jurassic monzonite, Cretaceous plutonic, volcanic, and sedimentary rocks, and Tertiary (Paleocene and Oligocene) volcanic and plutonic rocks. An Upper Cretaceous diorite stock (figs. 3 and 5) is combined in the basement unit, but was modeled separately because it is water bearing, and may be important to the local hydrology. The middle unit is composed entirely of the Miocene Nogales Formation (figs. 3-5), which consists of volcaniclastic sandstone, conglomerate, siltstone, and claystone; maximum thickness for unit is about 950 meters $(\mathrm{m})$. The geology and hydrology of the Nogales Formation have been poorly understood because limited data have been collected for the formation (Erwin, 2007; Nelson, 2007); as a result, the formation has not been widely developed as a source of groundwater in the upper Santa Cruz Basin. However, new hydrogeologic investigations (Page and others, 2016a) indicate parts of the formation may be productive aquifers, and a potential deeper source of groundwater for the area. The upper unit consists of late Miocene to early Pleistocene basin-fill deposits, and early Pleistocene to Holocene alluvium, combined (figs. 3-5). The maximum thickness for the unit is about $180 \mathrm{~m}$.

One limitation of the 3D model, and an important reason for its original construction, is the general lack of subsurface geologic data for the area, except for driller logs from shallow water wells and a few deeper wells. Because subsurface data for the area are sparse, hydrogeologic unit subsurface elevations in the 3D model were estimated based on a combination of surface geologic map data (Page and others, 2016b) projected into the subsurface and geophysical data modeling (Bultman and Page, 2016). Therefore, the configuration, geometry, and structure of the modeled geology currently represents the best interpretation of the subsurface geology, especially in areas with less data, and the 3D model serves as an important starting point for further evaluation of groundwater resources in the basin.

\section{Geologic Framework}

\section{D Model Hydrogeologic Units}

\section{Lower Basement Confining Unit}

The lower basement confining unit consists of the Jurassic Quartz Monzonite of Mount Benedict, sedimentary, volcanic, and plutonic rocks of the Upper Cretaceous Salero Formation, and Oligocene volcanic and plutonic rocks of the Grosvenor Hills Volcanics (figs. 3 and 4). Also included in the lower basement unit is an Upper Cretaceous diorite stock (figs. 3-5), which was modeled separately from the unit because it may be important to the local hydrology. The erosional top surface of the basement unit is complex and faulted (fig. 6), because of multiple stages of tectonism in the region. The most recent tectonism includes Tertiary Basin and Range extension, which occurred in southern Arizona from about 20 to 10 mega-annum (Ma) (Menges, 1981; Menges and Pearthree, 1989). Major episodes of pre-Tertiary deformational events include Cretaceous plutonism and faulting related to the Laramide orogeny (Simons, 1974; Drewes, 1980), and tectonic events during the early and middle Mesozoic, and the Precambrian (Drewes, 1980).

\section{Jurassic Rocks}

The oldest rocks in the lower basement unit include the Quartz Monzonite of Mount Benedict of Late to Middle Jurassic age (160 + 19 Ma and $164+19$ Ma; Simons, 1974), which are exposed in the Mount Benedict horst block, in the central part of the study area (figs. 2, 6, and 7). The monzonite is highly deformed and is intruded by numerous diorite and diabase dikes (fig. 8), which were mapped by Simons (1974). The dikes are mostly northwest striking and southwest dipping (Simons, 1974), and although most are a few meters thick, some are as much as 60 meters $(\mathrm{m})$ thick. Although the monzonite is exposed at the surface in the horst block, these rocks form basement below the Miocene Nogales Formation and late Miocene to Holocene surficial deposits in most of the model area. The monzonite generally forms a confining unit in the study area; however, Erwin (2007) reported it to locally be an aquifer based on aquifer tests in the Kino Springs 7.5' quadrangle (fig. 1); artesian flow was observed from some intervals in the monzonite, and hydraulic conductivity values were relatively low, estimated at less than 1 foot per day.

\section{Upper Cretaceous Rocks}

\section{Salero Formation}

Upper Cretaceous rocks in the region include the Salero Formation of Drewes (1968). The lower part of the Salero Formation unconformably overlies the Quartz Monzonite of Mount Benedict along the Santa Cruz River southeast of Sonoita Creek and northwest of Guevavi Canyon (figs. 2, 3, and 9). Most of the unit in that area consists of thick-bedded, well-consolidated, gently dipping conglomerate and sandstone (fig. 9), with clasts of silicic volcanic rocks, sandstone, and siltstone, and some granite; thickness of the unit in this area ranges from 50 to $150 \mathrm{~m}$. The Salero Formation is exposed in the San Cayetano Mountains on the north edge of the study area (figs. 2 and 3), where it is greater than $400 \mathrm{~m}$ thick, and consists mainly of light-brown conglomerate and sandstone, green and gray argillite and sandstone, and pale red quartzite and conglomerate. These rocks are intruded by abundant west- to northwest-trending, reddish-gray latite dikes and plugs of Tertiary age (Simons, 1974; Drewes, 1980). Drewes 


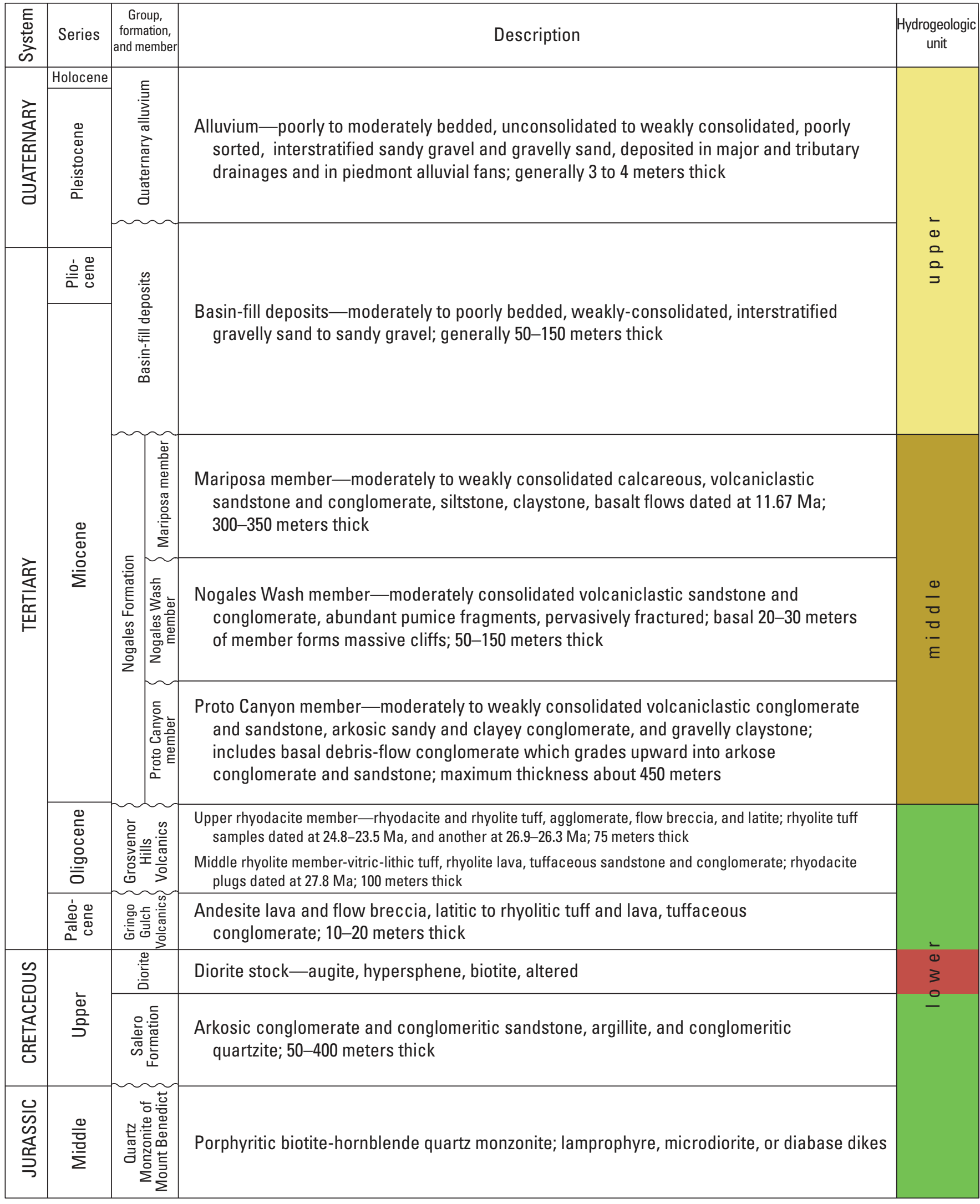

Figure 4. Geologic units in the Rio Rico and Nogales 7.5' quadrangles, Arizona, from Page and others (2016b); units are combined to define the three modeled hydrogeologic units, which are color-coded in vertical column on right side of chart (Ma, Mega-annum); green and red colors represent lower hydrogeologic unit (basement confining unit); gold color represents the middle hydrogeologic unit (Miocene Nogales Formation); and yellow color is the upper hydrogeologic unit (late Miocene to Holocene surficial deposits). 


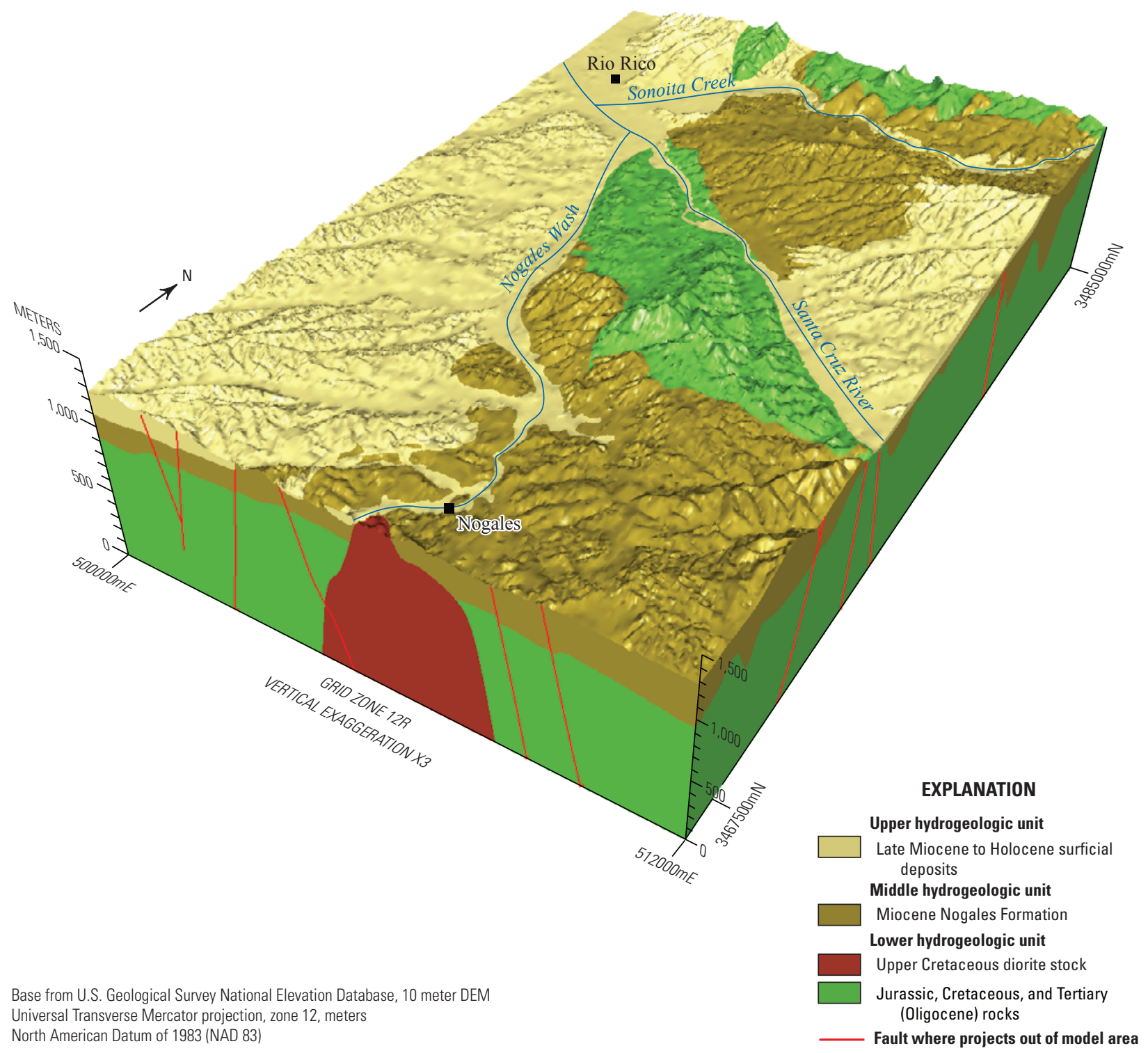

Figure 5. View to the northwest of the three-dimensional hydrogeologic model, showing the distribution of hydrogeologic units.

(1968) reported a K-Ar age of $72.5+2.2 \mathrm{Ma}$ (biotite) from a welded tuff in the formation in the Santa Rita Mountains, about 10 kilometers $(\mathrm{km})$ north of the area, and Hayes (1970) reported this K-Ar date combined with stratigraphic position to indicate a late Campanian to earliest Maastrichtian age (about 72 to $69 \mathrm{Ma}$ ) for the formation. Although the Salero Formation is included in the lower basement confining unit in the study area, the formation may locally be an aquifer in the region, based on wells drilled in the Sonoita Creek Ranch area, about $25 \mathrm{~km}$ northeast of the area, which indicated some water-producing intervals in the unit (Erwin, 2007).

\section{Diorite Stock}

An Upper Cretaceous diorite stock is included in the lower basement confining unit along the southern edge of the study area (figs. 3 and 5). The diorite intruded the Jurassic
Quartz Monzonite of Mount Benedict, and its subsurface geometry was interpreted based on geophysical data. The stock was modeled separately from the basement unit because it is highly weathered and fractured, and parts of the stock were observed to be water-bearing, based on unpublished borehole data (Steven Nicely, written commun., 2013). These data indicated the borehole encountered the water table at a depth of $40 \mathrm{~m}$.

\section{Tertiary Volcanic and Plutonic Rocks}

Oligocene volcanic and plutonic rocks are included in the lower basement confining unit, and consist primarily of the Oligocene Grosvenor Hills Volcanics. The Paleocene Gringo Gulch Volcanics are also included in the lower basement unit, but are not discussed here because of limited exposure along the northeast edge of the study area (Page and others, 2016b); 


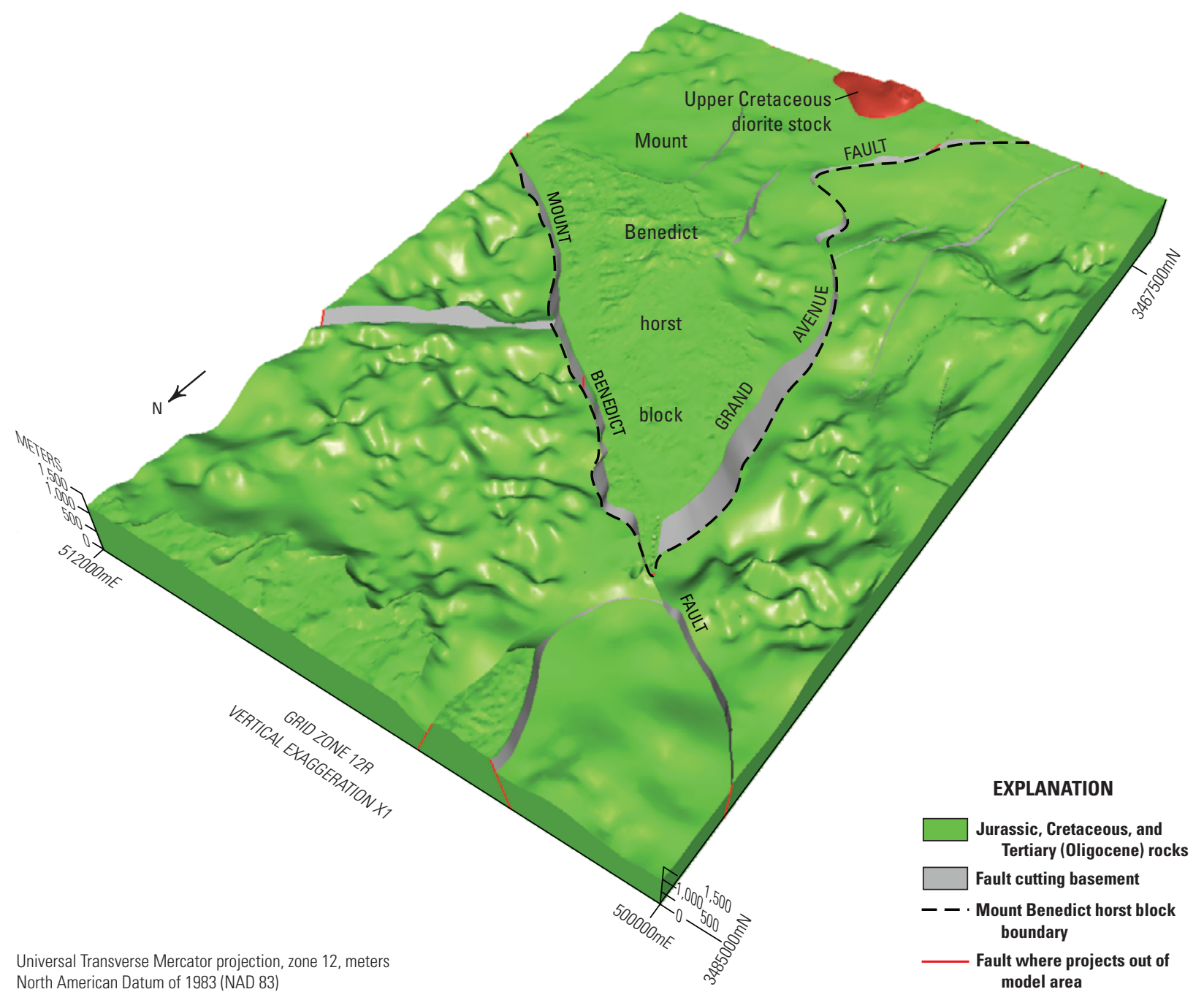

Figure 6. View to southeast showing the complex and faulted top surface of the basement confining unit, which was modeled based on a combination of geologic map and cross section data from Page and others (2016b) and geophysical data (Bultman and Page, 2016).

these rocks are more widely exposed adjacent to the study area, near Patagonia, Arizona (fig. 1).

\section{Oligocene Grosvenor Hills Volcanics}

The Grosvenor Hills Volcanics (Drewes, 1968) are exposed in the southern Grosvenor Hills (figs. 1-3), in the northern part of the study area, and consist mostly of rhyolite and rhyodacitic tuff, vitric lithic tuff, agglomerate, flow breccia, and latite. Thickness of the unit in the area is about $175 \mathrm{~m}$. These rocks are well exposed to the north of the study area in the Grosvenor Hills, and age-equivalent rocks are exposed to the west in the Atascosa and Tumacacori Mountains (fig. 1). Drewes $(1968,1972)$ subdivided the Grosvenor Hills Volcanics into a basal gravel and silt, a middle rhyolite member dated at 28 to $27 \mathrm{Ma}$ (Drewes, 1968), and an upper rhyodacite member dated at 26 to $23 \mathrm{Ma}$ (Page and others, 2016a); the basal member is not exposed in the study area. The sequence is intruded by 28 to 26 Ma rhyodacite and granodiorite laccoliths, dikes, and plugs (Drewes, 1971, 1980; Page and others, 2016b). The Grosvenor Hills were interpreted to be underlain by a thick, subsurface intrusion, based on a corresponding $10 \mathrm{~km}$ diameter, circular, positive magnetic anomaly (Gettings, 2002).

We collected and analyzed tuff samples from the Grosvenor Hills Volcanics in the area, and samples had relatively low effective porosity values at about 7 percent (Page and others, 2016a), suggesting these rocks may not be good aquifers based only on porous media flow. Although included as part of the lower basement confining unit, Oligocene volcanic rocks may be local aquifers in the region where fractured. Volcanic rocks equivalent to the Grosvenor Hills Volcanics in the Atascosa and Tumacacori Mountains (fig. 1) are highly fractured, and preliminary investigation of airborne electromagnetic data indicates some highly conductive zones, which may represent saturated volcanic rocks in the subsurface, in a fractured volcanic aquifer. 


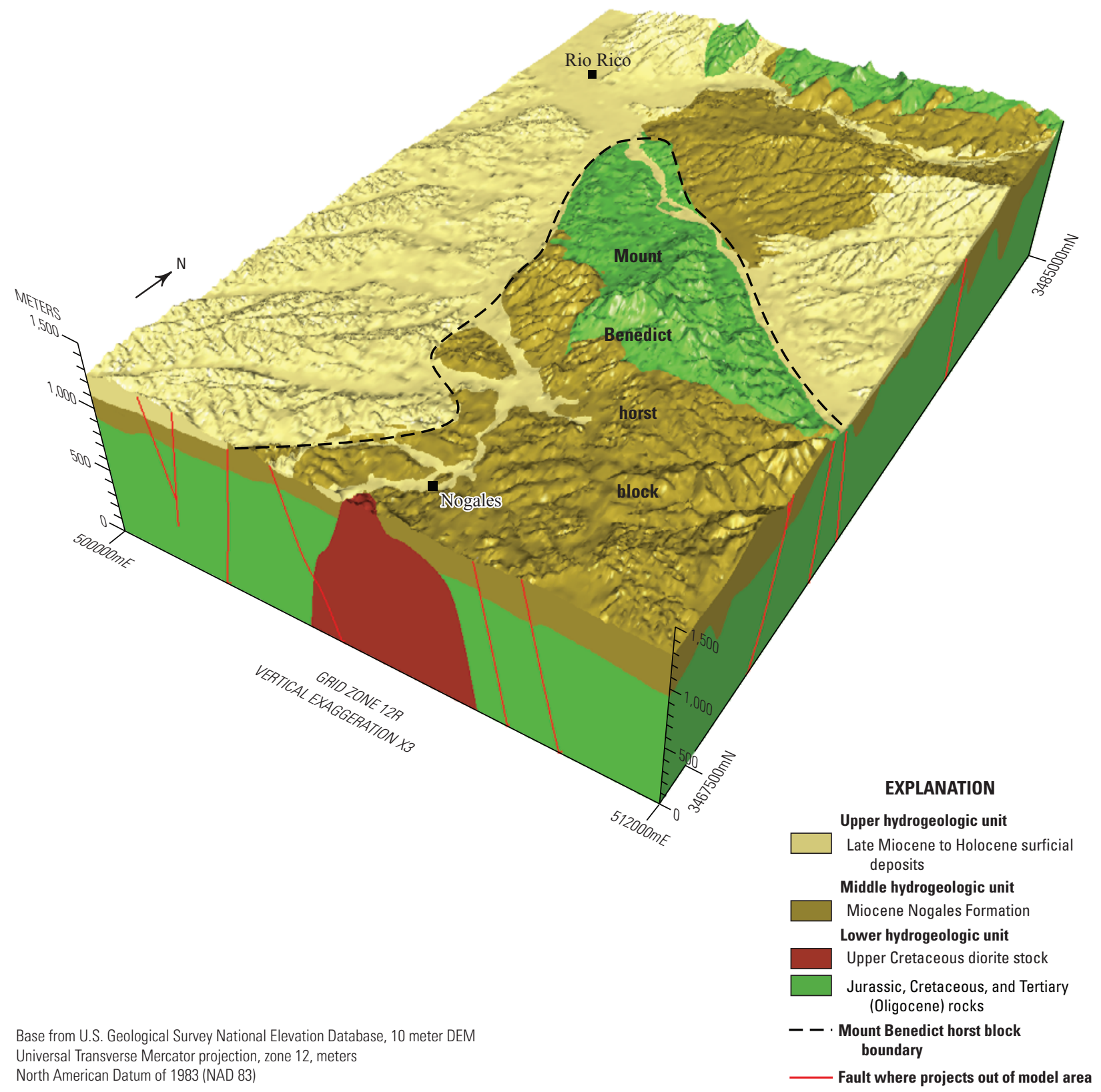

Figure 7. View to northwest of three-dimensional model, showing location of the Mount Benedict horst block at the surface, in relation to the modeled hydrogeologic units. The horst block is the main structural feature in the model area, and is a triangular zone of uplifted Jurassic Quartz Monzonite of Mount Benedict and overlying members of the Nogales Formation. 


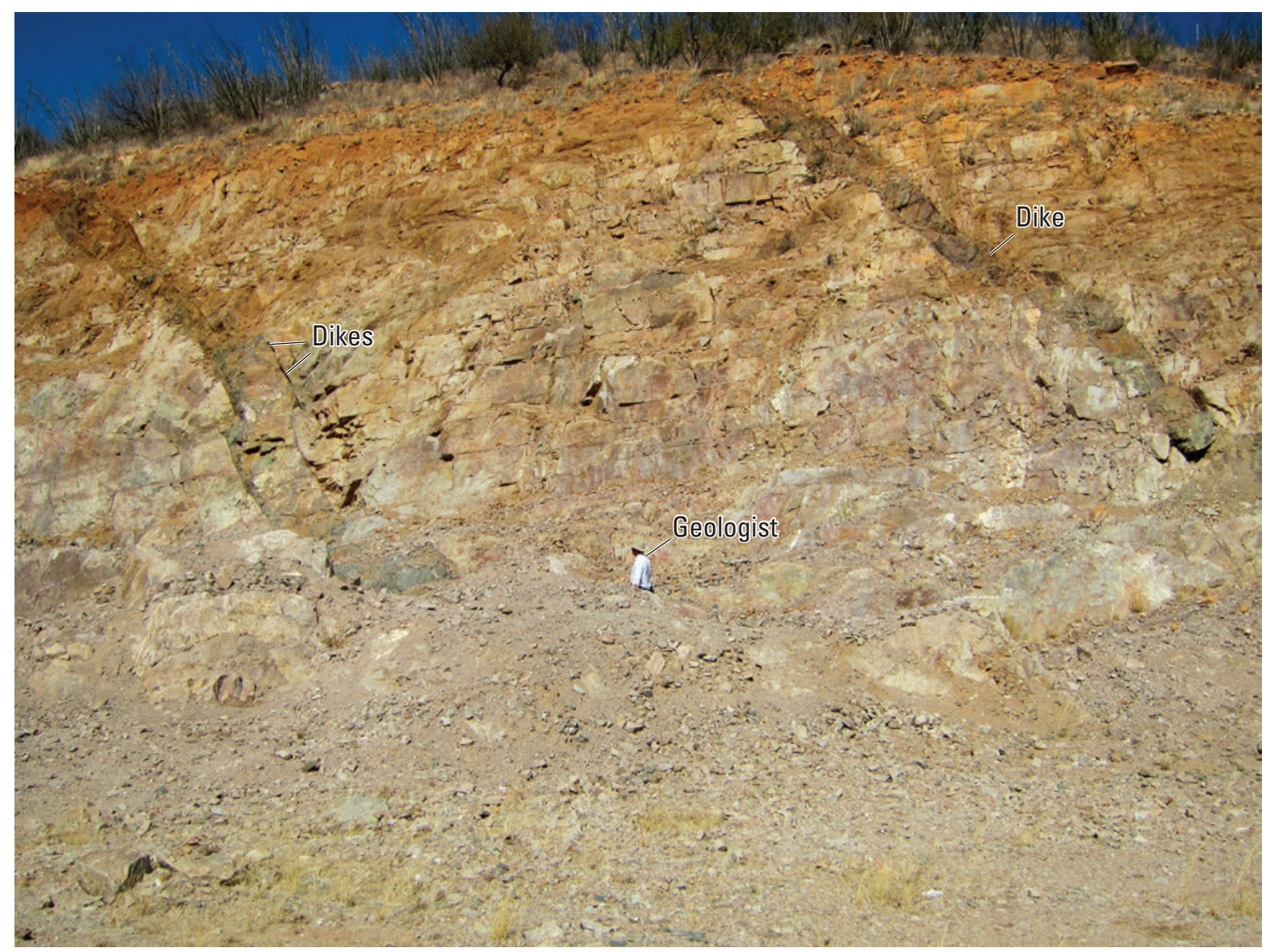

Figure 8. View to the north of Quartz Monzonite of Mount Benedict south of Mount Benedict (see figure 2). Darkgray colored, northeast-dipping diabase dikes are shown intruding monzonite; geologist in center between the two dikes for scale.

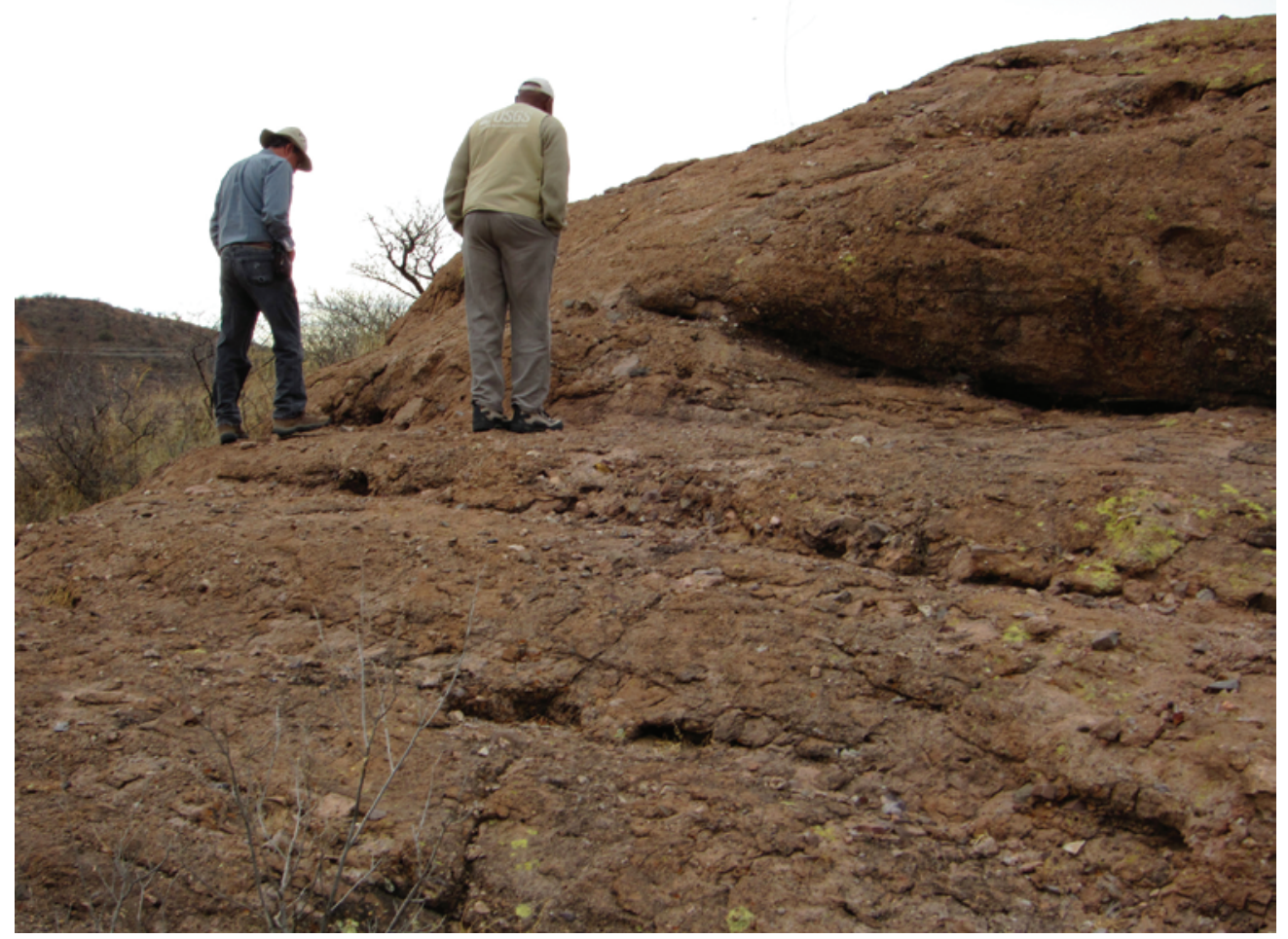

Figure 9. Outcrops of the Salero Formation along Santa Cruz River, south of Sonoita Creek and north of Guevavi Canyon. Conglomerate is well consolidated and has clasts mostly of silicic volcanic rocks, sandstone and siltstone, and granite. 


\section{Middle Unit Consisting of the Miocene Nogales Formation}

The Nogales Formation was originally named by Simons (1974) for exposures in Nogales, Arizona, and areas to the east and north. Page and others (2016b) revised the stratigraphy of the Nogales Formation, and recognized three informal members for the formation in the study area; these include (from base to top) the Proto Canyon, Nogales Wash, and Mariposa members. Surface distribution of the members in the area is shown in figure 3 . Figure 10 shows the combined informal members of the Nogales Formation in the 3D model area, which have a total thickness of about $950 \mathrm{~m}$ (Page and others, 2016b). The formation locally overlies the Jurassic Quartz Monzonite of Mount Benedict, which was a local source area for sediments in the formation. The Oligocene Grosvenor Hills Volcanics, and equivalent rocks to the west in the Atascosa and Tumacacori Mountains, were a regional source for the sediments in the formation, based on the presence of pumice and volcanic detritus in most sediments. The geologic summary of the Nogales Formation presented here contains greater detail than the other hydrogeologic units, because (1) its hydrogeologic characteristics have been poorly known, and (2) new studies (Page and others, 2016a) indicate parts of the formation may be productive aquifers, and a potential deeper source of groundwater for the upper Santa Cruz Basin.

\section{Proto Canyon Member}

The lower member of the Nogales Formation is the Proto Canyon member (figs. 3 and 4), named for exposures in Proto Canyon, in the southeastern part of the area (fig. 2). South of Mount Benedict (figs. 2 and 3), the basal part of the Proto Canyon member consists of distinctive debris-flow conglomerate which grades upward into arkosic conglomerate and sandstone. The basal coarse debris-flow conglomerate consists entirely of monzonite clasts, is primarily clast supported, and is well exposed near the contact with the Jurassic monzonite. These beds grade upward into distinctive weakly consolidated sequences of pale-reddish-brown arkosic conglomerate and sandstone, and some beds of poorly sorted debris-flow conglomerate with subangular, monzonite boulders, cobbles, and pebbles, in a sandy matrix. The basal debris-flow conglomerate and arkosic units are well exposed in the basin north of Proto Canyon and State Highway 82, and south of Mount Benedict (fig. 2). The thickness of the basal debrisflow conglomerate and arkosic units combined is variable, but estimated to be about 100 to $250 \mathrm{~m}$ thick.

Geologic units in the middle part of the Proto Canyon member, above the basal conglomerate and arkosic units, are exposed in Proto Canyon south of State Highway 82, where they consist of cliff-forming, fining-upward, cyclic fluvial sequences of volcaniclastic conglomerate, sandstone, and siltstone, and some debris-flow conglomerate. The finingupward cyclic fluvial sequences grade upward into alternating beds of thin-bedded yellowish-gray volcaniclastic sandstone and conglomeritic sandstone, interbedded red and gray sandy claystone, and red arkosic, clayey and sandy conglomerate, best exposed in the Yerba Buena Canyon area (figs. 2 and 11); the claystone beds may be local confining units in the area.

The upper part of the Proto Canyon member consists mainly of pinkish-gray to yellowish-gray, moderately consolidated, mostly poorly sorted, volcaniclastic sandstone and conglomerate exposed in the Grand Avenue area, north of Mariposa Road (figs. 2 and 12). The sandstone and conglomerate beds in the upper part of the member are similar in appearance to clastic units in the Nogales Wash member of the Nogales Formation, but the Proto Canyon member units are generally thinner bedded and have abundant monzonite clasts, reflecting locally derived detritus from the Quartz Monzonite of Mount Benedict.

The thickness of the Proto Canyon member is highly variable, but maximum thickness in the area is about $450 \mathrm{~m}$ (Page and others, 2016b). The Proto Canyon member is mostly exposed south of Mount Benedict, east of the Nogales urban area, west of the Santa Cruz River, and from Proto Canyon southeastward to across the international border (figs. 2 and 3). Other exposures of the Proto Canyon member are in the Sonoita Creek area, where the member laps onto the Grosvenor Hills Volcanics (figs. 2 and 3). In this area, the lower part of the member is pinkish-gray, cliff- to ledge-forming, poorly sorted volcaniclastic conglomerate and sandstone containing clasts and grains composed of mostly white and red porphyritic volcanic rocks, brownish-gray rhyodacite, and some pumice and latite derived from the Grosvenor Hills Volcanics. The upper part of the member is a sequence of mostly thin-bedded, fine-grained, moderately sorted, volcaniclastic sandstone and conglomeritic sandstone, which weathers to form distinctive rounded ledges.

\section{Nogales Wash Member}

The middle member of the Nogales Formation is the Nogales Wash member, named for exposures in the Nogales Wash area, south of Mariposa Road (fig. 2). The member is only present in the southern part of the study area (fig. 3), and outcrops extend from Ephraim Canyon on the west, to about $4 \mathrm{~km}$ east of Grand Avenue (fig. 2). The member typically contains volcaniclastic conglomerate and sandstone (fig. 13) with abundant pumice fragments, and it generally lacks claystone beds unlike the other two members of the formation. Outcrops of the member are highly fractured in the area. The Nogales Wash member is unconformable with the Proto Canyon member, and laps onto the lower part of the latter member along State Highway 82, about $1.5 \mathrm{~km}$ northeast of Grand Avenue (fig. 2). The Nogales Wash member is estimated to be as much as $150 \mathrm{~m}$ thick. The basal 20 to $30 \mathrm{~m}$ of the unit contains distinctive massive cliffs of yellowish-gray to pinkish-gray, moderately consolidated volcanic sandstone and conglomeritic sandstone. Most other parts of the member contain alternating beds of thin- to thick-bedded, volcaniclastic sandstone and conglomeritic sandstone, which locally display tabular-planar 
$\boldsymbol{A}$

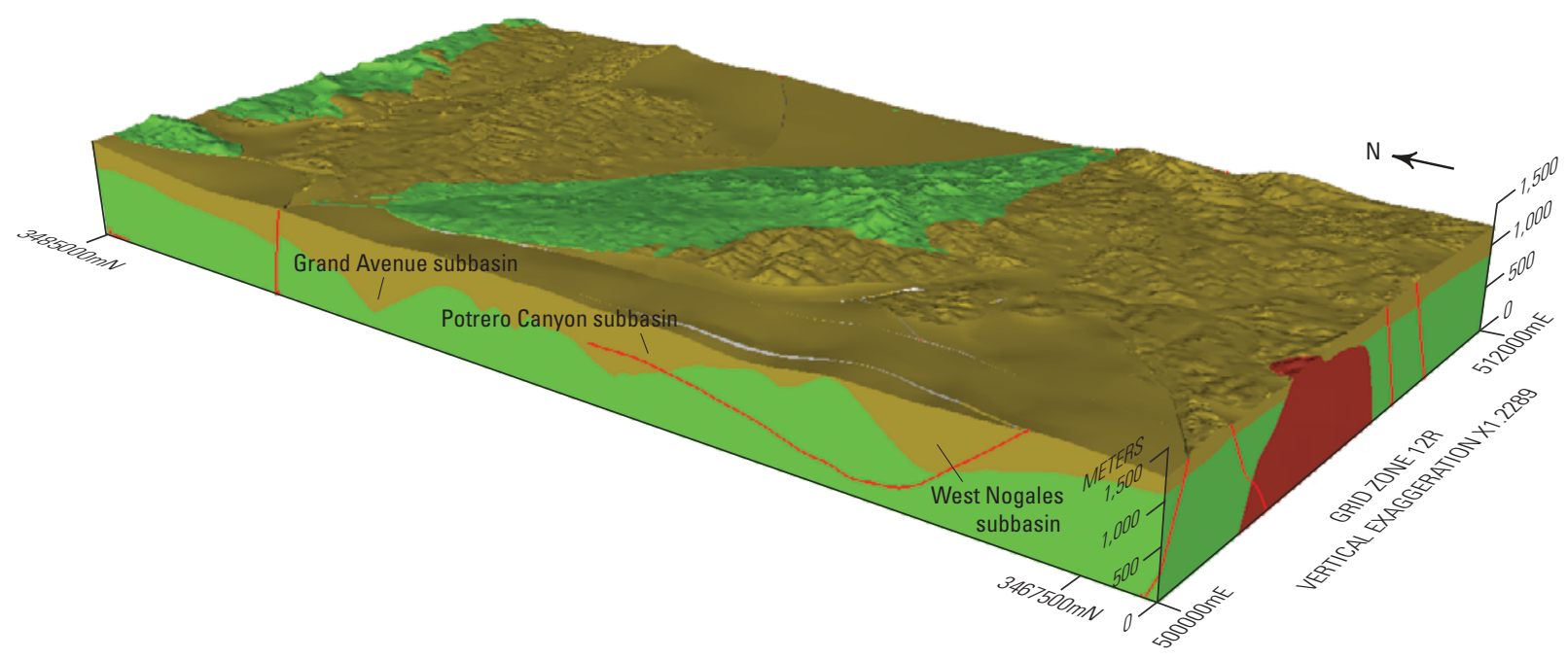

$\boldsymbol{B}$

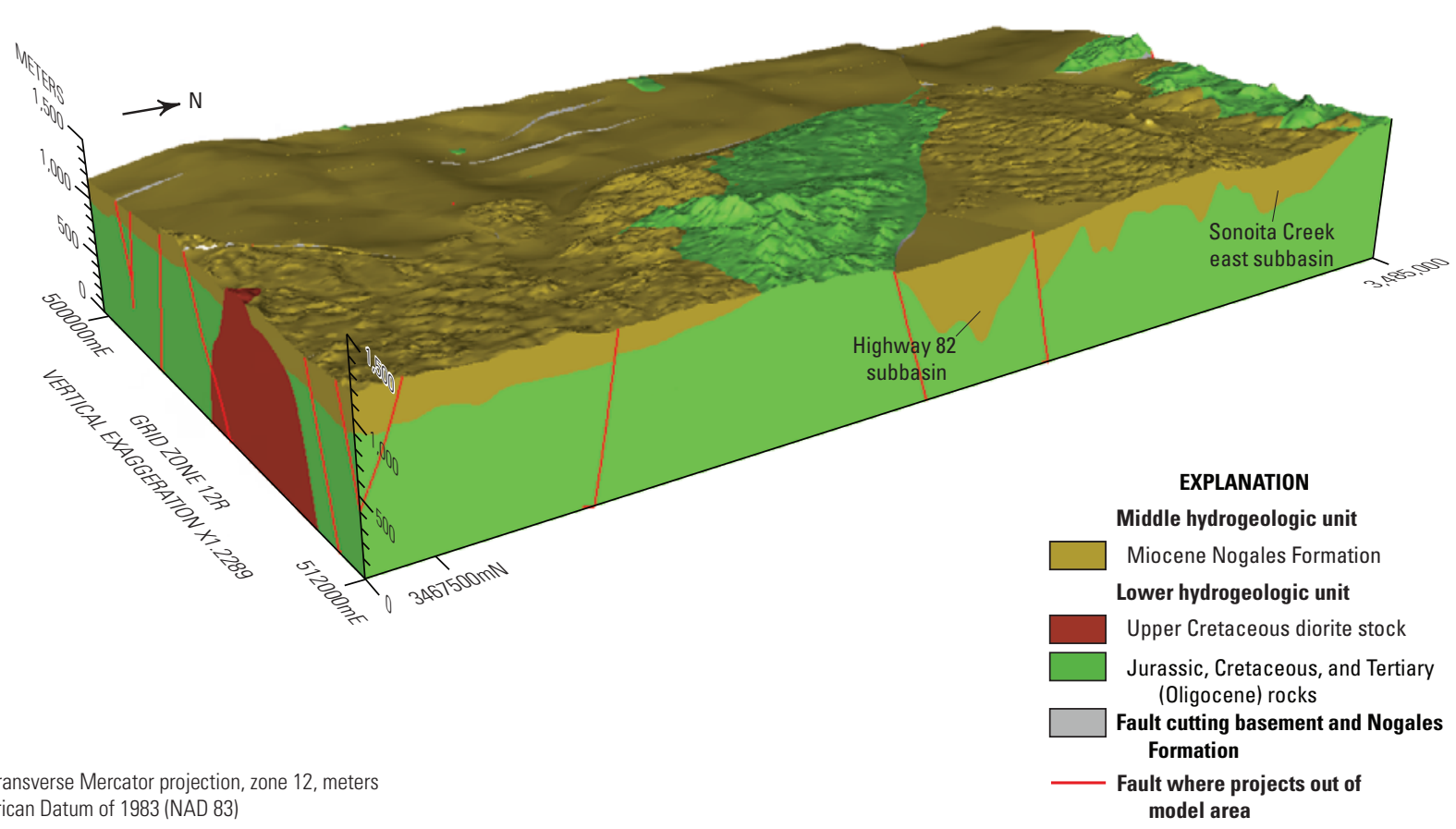

Universal Transverse Mercator projection, zone 12, meters North American Datum of 1983 (NAD 83) model area

Figure 10. A, view to the northeast of three-dimensional model showing the middle hydrogeologic unit of the Nogales Formation overlying basement. Upper hydrogeologic unit (late Miocene to Holocene deposits) stripped off top of model to show surface defining the top of the Nogales Formation. X-axis boundary slicing was conducted along the west model edge, parallel with an approximate north-south axis which traverses the deepest parts of the three interpreted Nogales Formation subbasins; the subbasins are defined by geophysical data (Bultman and Page, 2016) and are further discussed in the Geophysical Data section of this report. 1.2 vertical exaggeration. $B$, view to the northwest of the three-dimensional model showing the middle hydrogeologic unit of the Nogales Formation above the basement confining unit, including the Upper Cretaceous diorite stock. X-axis boundary slicing was conducted through the approximate axes along the deepest parts of the Highway 82 and Sonoita Creek east subbasins, defined by Bultman and Page (2016). 


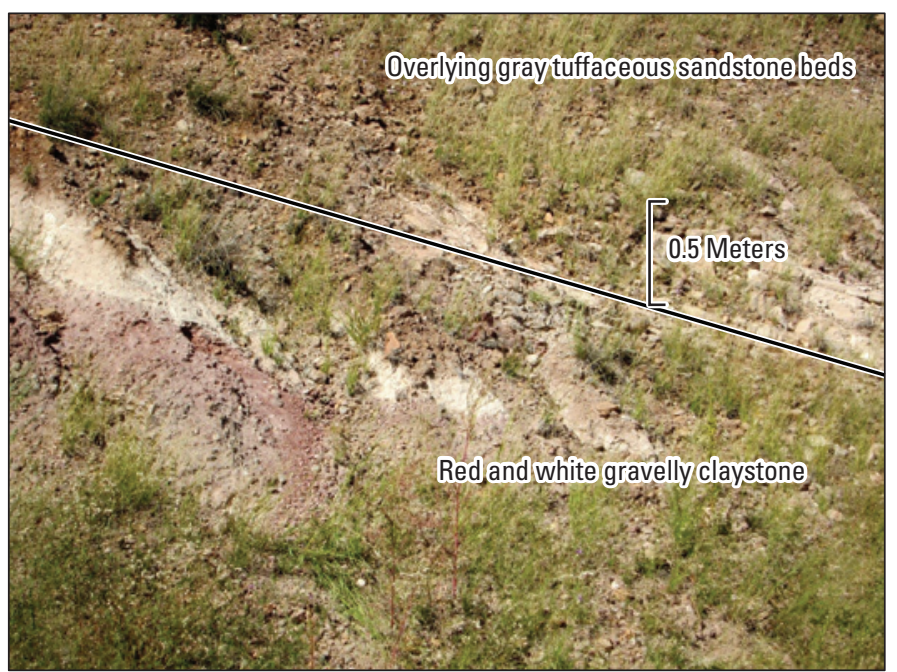

Figure 11. Red and white gravelly claystone and overlying gray tuffaceous sandstone beds in the middle part of the Proto Canyon member in Yerba Buena Canyon.

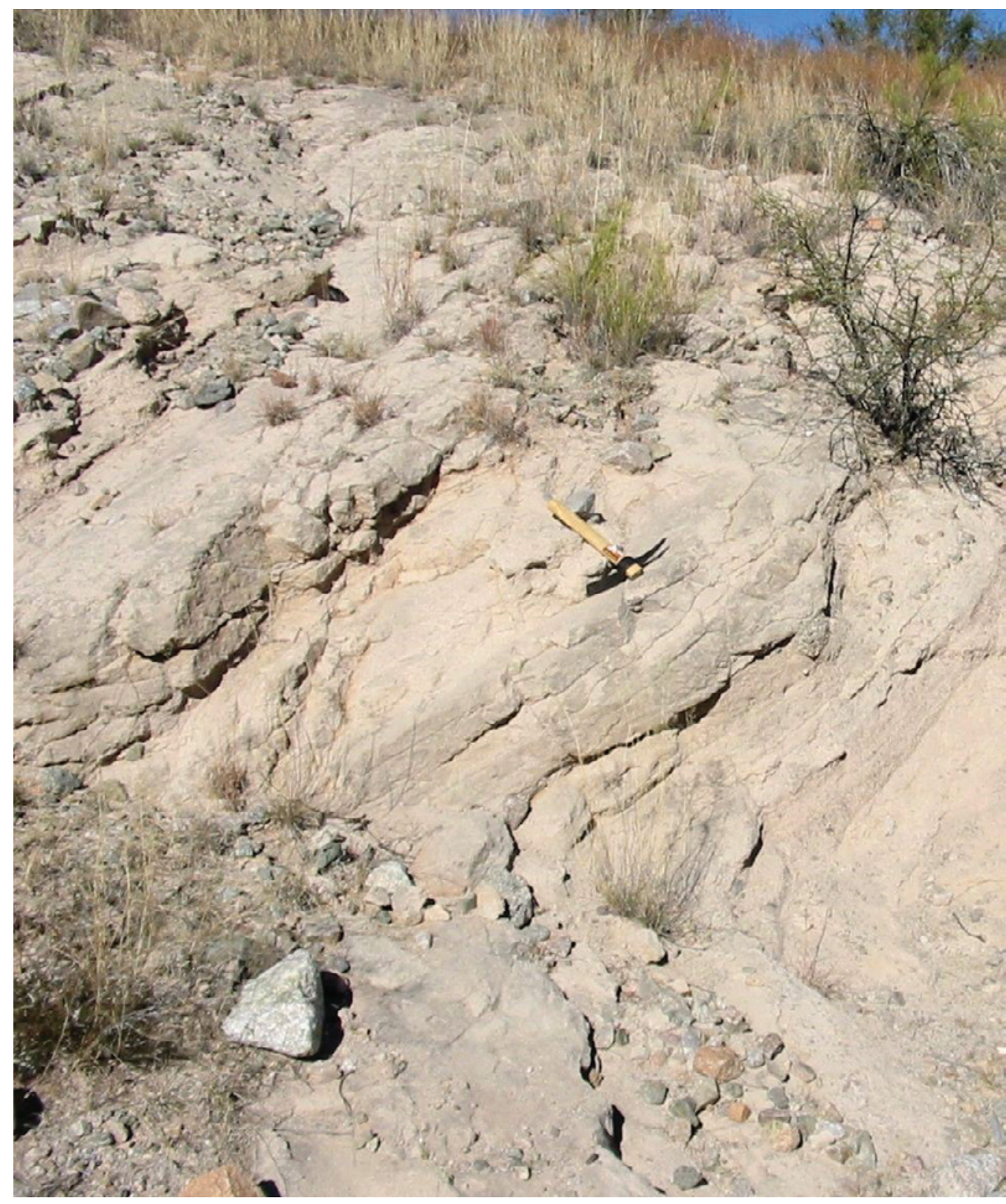

Figure 12. Pinkish-gray, moderately consolidated volcaniclastic sandstone in the uppermost part of the Proto Canyon member, between Interstate 19 and Grand Avenue, and north of Mariposa Road. 


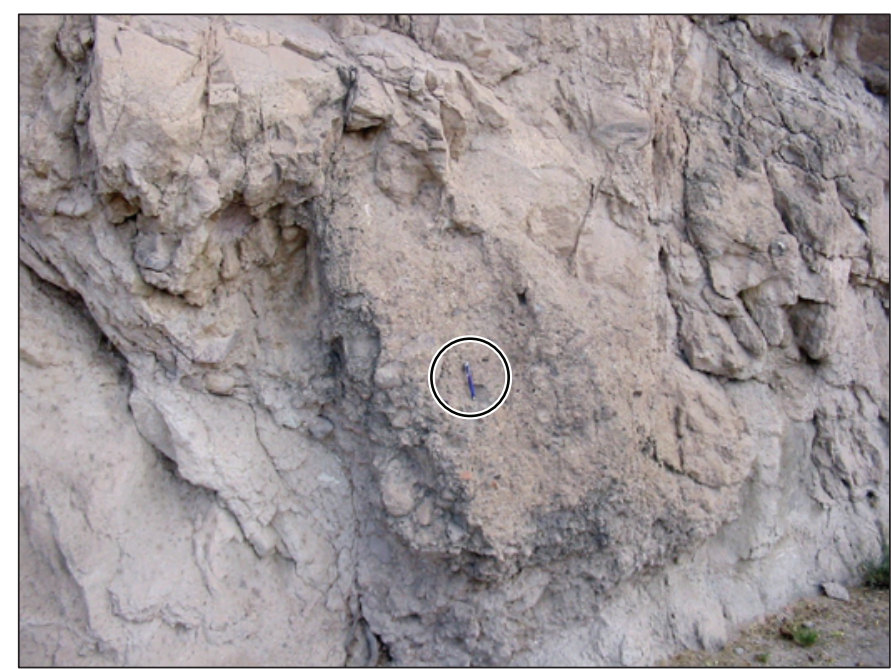

cross-bedding. Limitation of the member to the southern part of the model area, combined with onlapping relations with the lower Proto Canyon member, suggest the Nogales Wash sediments were deposited in a paleo-valley eroded into the Proto Canyon member, coincident with modern-day Nogales Wash (Page and others, 2016b).

\section{Mariposa Member}

The upper member of the Nogales Formation is the Mariposa member (Page and others, 2016b), named for outcrops north and south of Mariposa Road, between Interstate 19 and Grand Avenue (fig. 2). The member is also exposed in southeastern parts of the area, and in the basin south of
Figure 13. Massive, cliff-forming, moderately consolidated volcaniclastic sandstone and conglomeritic sandstone in the basal part of the Nogales Wash member along Grand Avenue, south of Mariposa Road; pen in center for scale. Note internal deformation including abundant fractures, and breccia zone in center of photograph; pen circled in center for scale.
Sonoita Creek and east of the Santa Cruz River (fig. 3). North of Mariposa Road along Interstate 19, the member consists of alternating beds of pale-red to pinkish-gray, coarse- to finegrained, volcaniclastic conglomeritic sandstone, sandstone, and minor siltstone (fig. 14). South of Mariposa Road between Interstate 19 and Grand Avenue, a massive claystone unit (fig. 15) represents playa deposits in an axial-basin facies of the member, based on its fine-grained character. About 30 to $40 \mathrm{~m}$ of the claystone unit is exposed, but total thickness may be $60 \mathrm{~m}$ or more, indicating the unit may locally be a significant confining unit. More subsurface data are needed to determine the claystone's lateral extent and thickness in the basin.

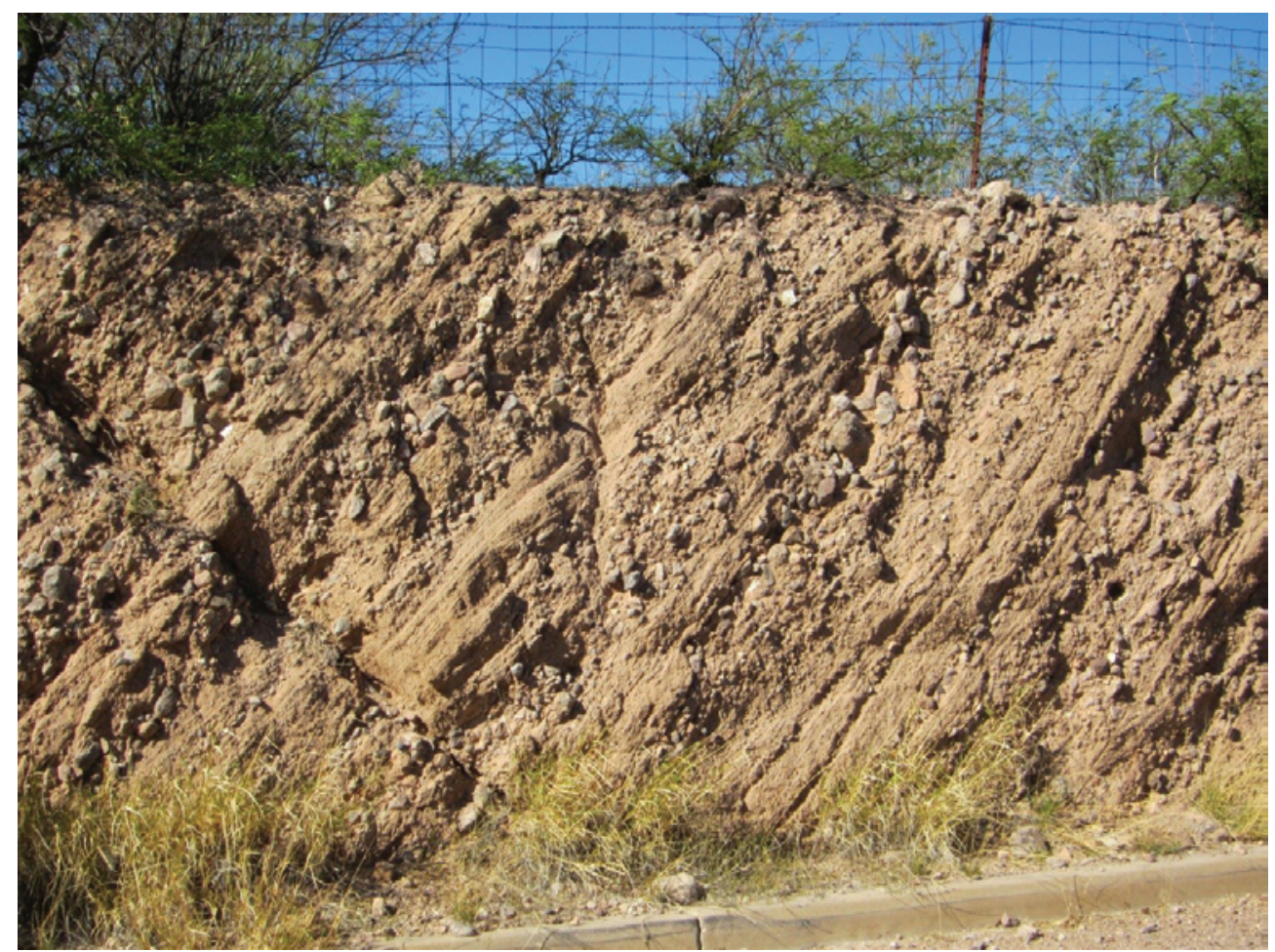

Figure 14. Faulted and highly rotated beds (dipping $48^{\circ}$ northwest) of Mariposa member in Interstate 19 area, north of Mariposa Road; beds consist of moderately sorted volcaniclastic conglomeritic sandstone, sandstone, and minor siltstone. Height of concrete curb in lower right is about 0.15 meter. 


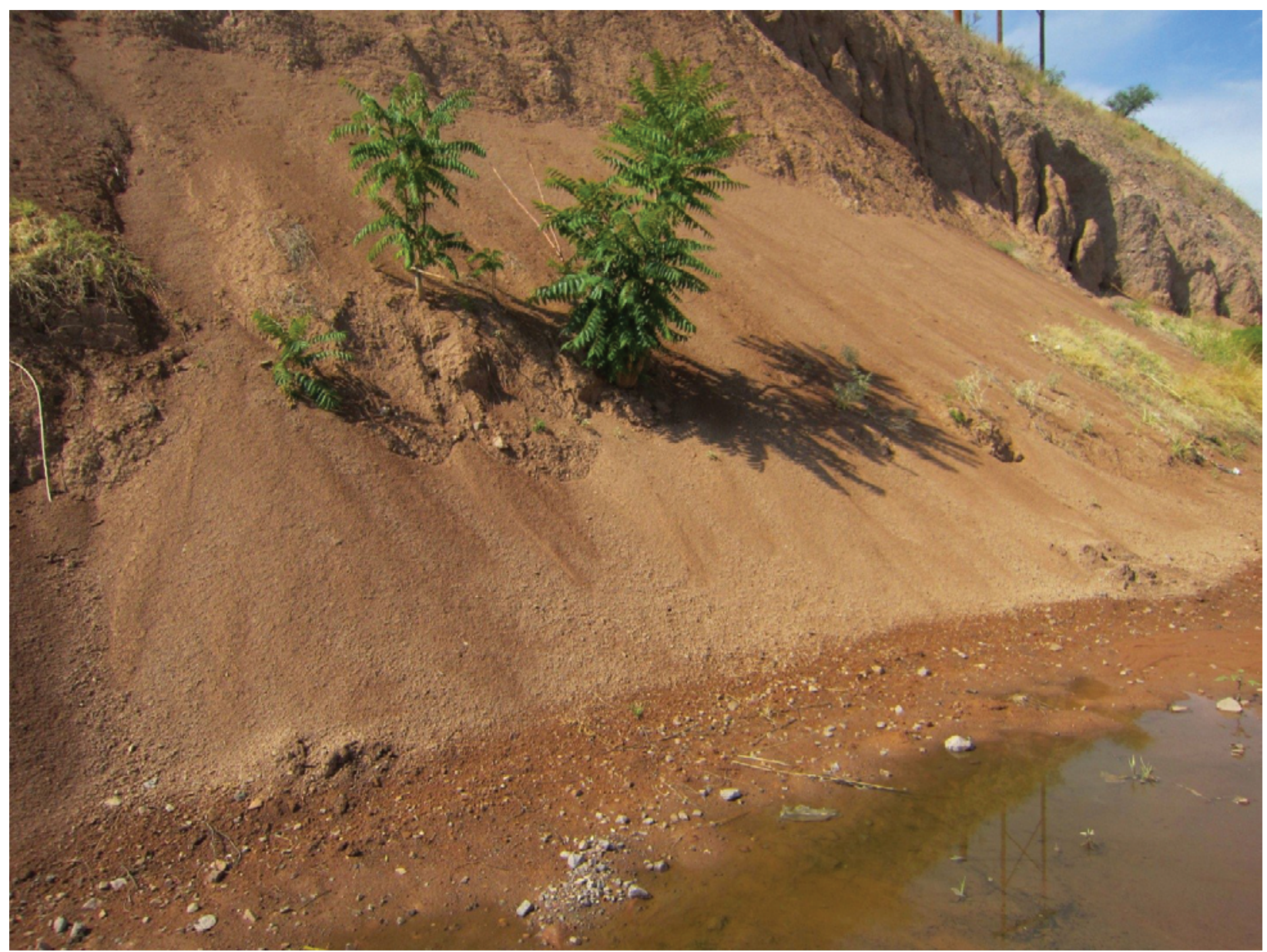

Figure 15. Massive claystone unit in the Mariposa member on south side of Mariposa Road, between Grand Avenue and Interstate 19. Unit may be significant local confining unit in the Mariposa member, although its subsurface thickness and lateral extent are poorly known; note unit holding water following rainstorm.

The Mariposa member is also exposed in the southeastern part of the area (fig. 3), southeast of Highway 82 and north of the international border, where lower parts of the member consist mostly of volcaniclastic, pebble conglomerate and sandstone, and some fine-grained, moderately sorted sandstone. In this area, clasts are mostly subangular, light-brownish-gray rhyolite that may be derived from an unidentified volcanic source likely in northeastern Nogales, Sonora. The member here also contains small discontinuous basalt flows which are about 2 to $5 \mathrm{~m}$ thick, and a sample from one flow dated near the international border yielded an ${ }^{40} \mathrm{Ar} /{ }^{39} \mathrm{Ar}$ geochronology plateau age (whole rock) of $11.67+0.09 \mathrm{Ma}$ (Page and others, $2016 \mathrm{~b}$ ); this date provides a minimum age for the Nogales Formation.

In the basin south of Sonoita Creek and east of the Santa Cruz River (fig. 2), the Mariposa member contains pinkishgray, alternating beds of volcaniclastic conglomeritic sandstone, sandstone, and some siltstone and claystone, like in the Mariposa Road type area, but units are generally thinner bedded and finer-grained than those in the type area, and consist mostly of alternating beds of fine-grained volcaniclastic sandstone, siltstone, and claystone. The Mariposa member in this area also contains claystone units similar to those in the Mariposa Road type area, but these units are thinner than those in the type area, range from about 0.5 to $3 \mathrm{~m}$ thick, and are generally interbedded with volcaniclastic sandstone beds.

\section{Hydraulic Properties and Hydrogeologic Characteristics of the Miocene Nogales Formation}

Published hydraulic conductivity data for the Nogales Formation are sparse; however, Erwin (2007) reported composite values of 0.4 and 0.5 feet per day ft/d (12 and 15 centimeters per day $[\mathrm{cm} / \mathrm{d}]$ ) from aquifer tests completed in wells penetrating post-Nogales alluvium and the Nogales Formation in the Kino Springs area (fig. 1). Nelson (2007) reported hydraulic conductivities for the Nogales Formation (based on aquifer tests west of Tubac, Arizona; fig. 1) in the upper Santa Cruz Basin at $0.17 \mathrm{ft} /$ day $(5.1 \mathrm{~cm} / \mathrm{d}), 0.3 \mathrm{ft} /$ day $(9.1 \mathrm{~cm} / \mathrm{d})$, and $0.43 \mathrm{ft} /$ day $(13.1 \mathrm{~cm} / \mathrm{d})$. 
New hydrogeologic investigations of the Nogales Formation (Page and others, 2016a) were conducted to evaluate the groundwater resource potential for the formation. Results of these investigations indicate parts of the formation may be productive aquifers and potential new deeper sources of groundwater for the area. Page and others (2016a) analyzed volcaniclastic sandstone samples from the formation, and reported effective porosity values ranging from 16 to 43 percent, and saturated hydraulic conductivity ( $\mathrm{SHC}$ ) values ranging from 4 to $57 \mathrm{~cm} / \mathrm{d}$. Matrix material in most samples consisted of pumice fragments, and some contained predominantly silt and clay. Our studies indicated samples with mostly silt and clay had lower porosity and SHC, compared to samples with mostly pumice, which had higher and wider ranges of porosity and SHC. Scanning electron microscope and $\mathrm{X}$-ray diffraction analyses indicated most samples contained the zeolite clinoptilolite, and some samples contained mixed layer smectite and illite clay. Samples with greater amounts of clinoptilolite and lesser amounts of clay had higher porosity and SHC, compared to those with greater amounts of clay and less clinoptilolite.
All members of the Nogales Formation are fractured and faulted (figs. 13, 14, 16, and 17) resulting from Tertiary Basin and Range extensional deformation, which was broadly contemporaneous with deposition of the Nogales Formation. These structures may have significant effect on groundwater flow in the upper Santa Cruz Basin. Although, many of the sediments in the formation have fabric characteristics, porosity, and SHC values indicating they may be productive aquifers based on porous media flow alone, the pervasive fracturing in these sediments may further enhance permeability and groundwater flow in these basin-fill aquifers by orders of magnitude.

\section{Upper Hydrogeologic Unit Consisting of Late Miocene to Early Pleistocene Basin-Fill Deposits, and Early Pleistocene to Holocene Alluvium, Combined}

The upper hydrogeologic unit includes late Miocene to early Pleistocene basin-fill deposits (map unit QTa from Page and others 2016b), and early Pleistocene to Holocene

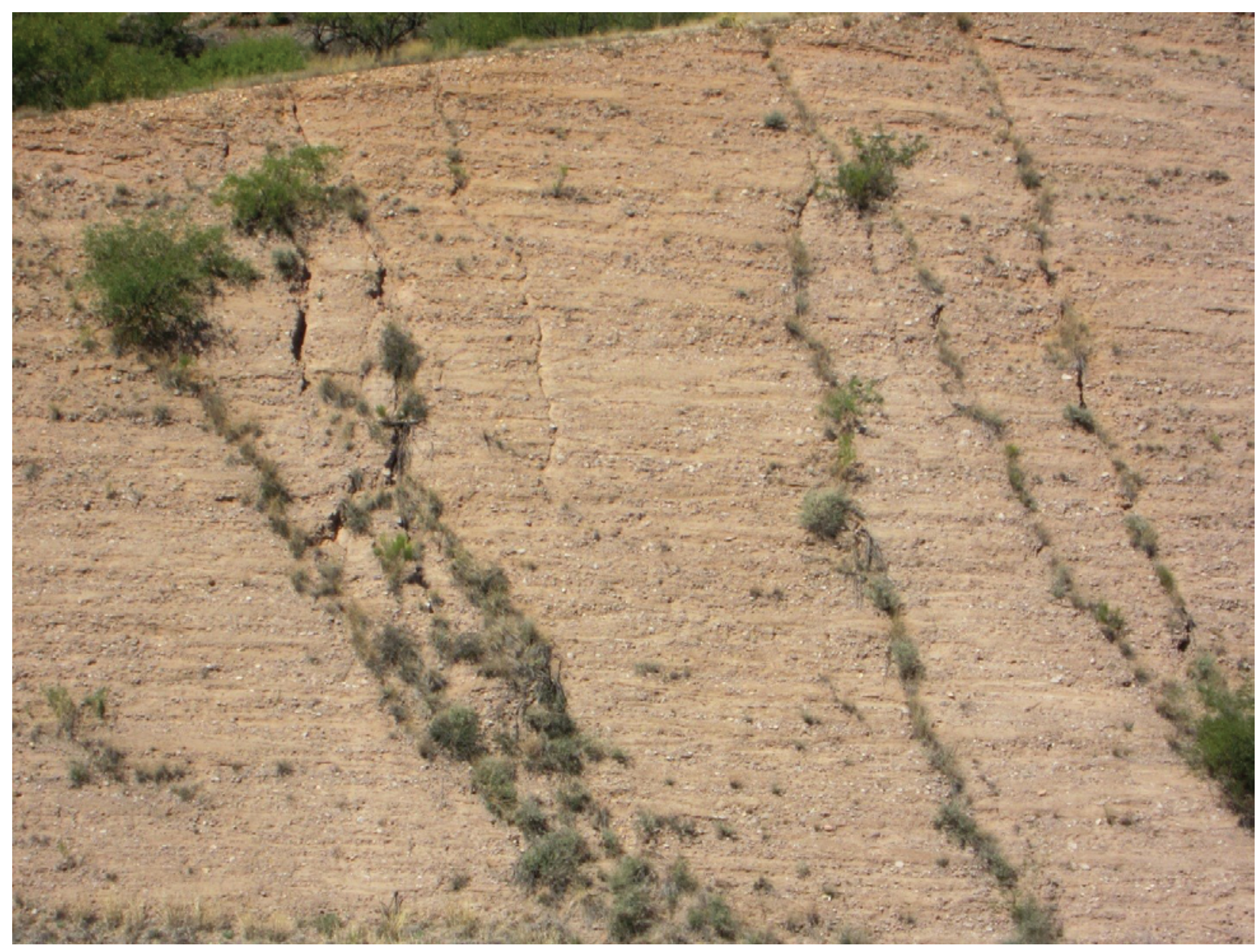

Figure 16. Subvertical fractures in Mariposa member in roadcut along Interstate 19, north of Mariposa Road; roadcut about 7 meters in height. 


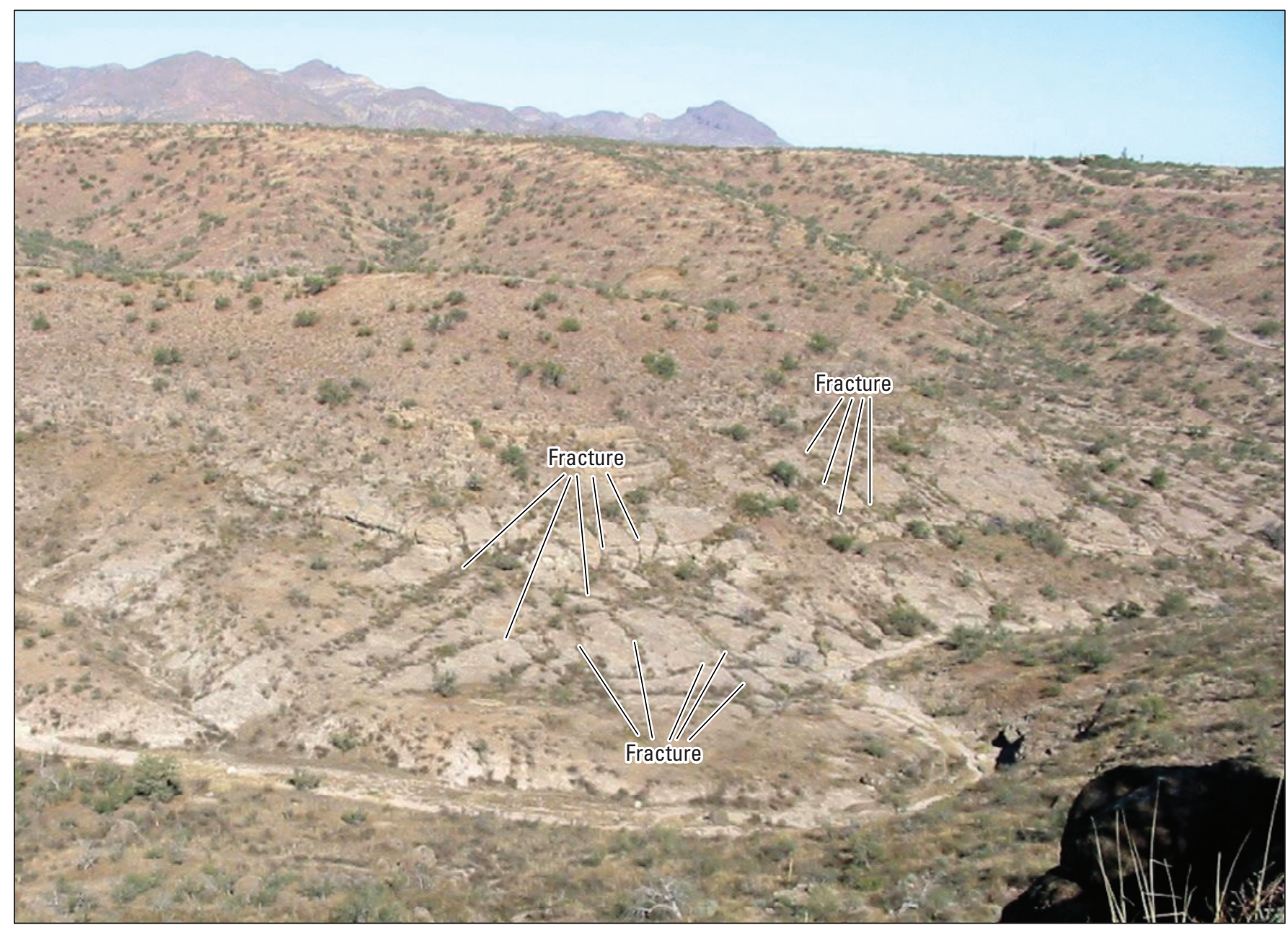

Figure 17. North view of intersecting fractures (accented by linear vegetation patterns) in volcaniclastic sandstone units in the Nogales Formation in the Agua Fria Canyon area; Tumacacori Mountains on the skyline; width of view about 250 meters across.

alluvium, combined, (fig. 4) The unit thickness is generally less than $200 \mathrm{~m}$, compared to nearly a kilometer thickness for the middle Nogales Formation hydrogeologic unit. Sediments of the upper unit are mostly exposed at the surface (fig. 18), except for some late Miocene to early Pleistocene basin-fill deposits which are concealed in places where overlain by thin veneers of early Pleistocene to Holocene alluvium.

\section{Late Miocene to Early Pleistocene Basin-Fill Deposits}

Late Miocene to early Pleistocene basin-fill deposits (unit QTa from Page and others, 2016b) are widely exposed in the western and northeastern parts of the study area (fig. 3). Basin-fill deposits are defined as mixtures of sand, gravel, and silt eroded from upland mountains or hills, and deposited into adjacent lowland basins. These deposits form sequences that unconformably overlie a variety of Tertiary strata (including Nogales Formation sediments and the Grosvenor Hills Volcanics), as well as many older basement units, which are exposed in dissected basins in the western, north-central and east-central sections of the area. Basin-fill deposits are overlain by thin and spatially restricted veneers of early Pleistocene to Holocene alluvium described in the early Pleistocene to Holocene Alluvium section below. Basin-fill deposits consist of reddish-brown to pinkish-gray, moderately to poorly bedded, and weakly consolidated interstratified gravelly sand to sandy gravel (fig. 19). The sediments typically display provenance relations and stratal dips consistent with fan deposition which occurred adjacent to the nearest highland basement source terrains. The absence of strongly rotated bedding, faults, or fractures indicates no significant post-depositional deformation in most of the unit. The primary exceptions are basal sections of the unit, which are faulted and fractured near some of the major exposed basinbounding faults (fig. 19B). Basin-fill deposits can generally be distinguished from the older Nogales Formation sediments by some combination of weaker consolidation, more diffuse and poorly differentiated interbedded sequences of sand and gravel, pinkish gray color, and development of a subvertical erosional fluting pattern which crosscuts bedding (fig. 19A). 
A

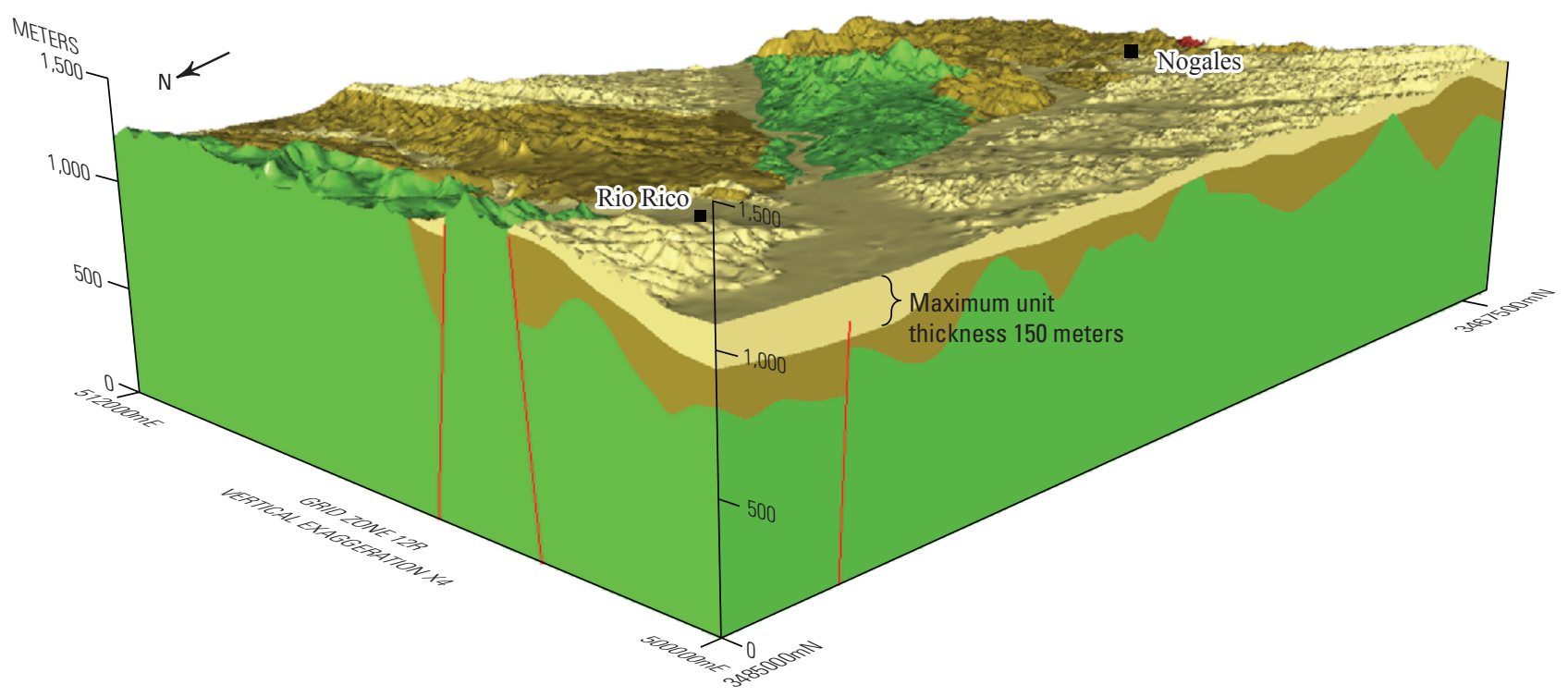

B

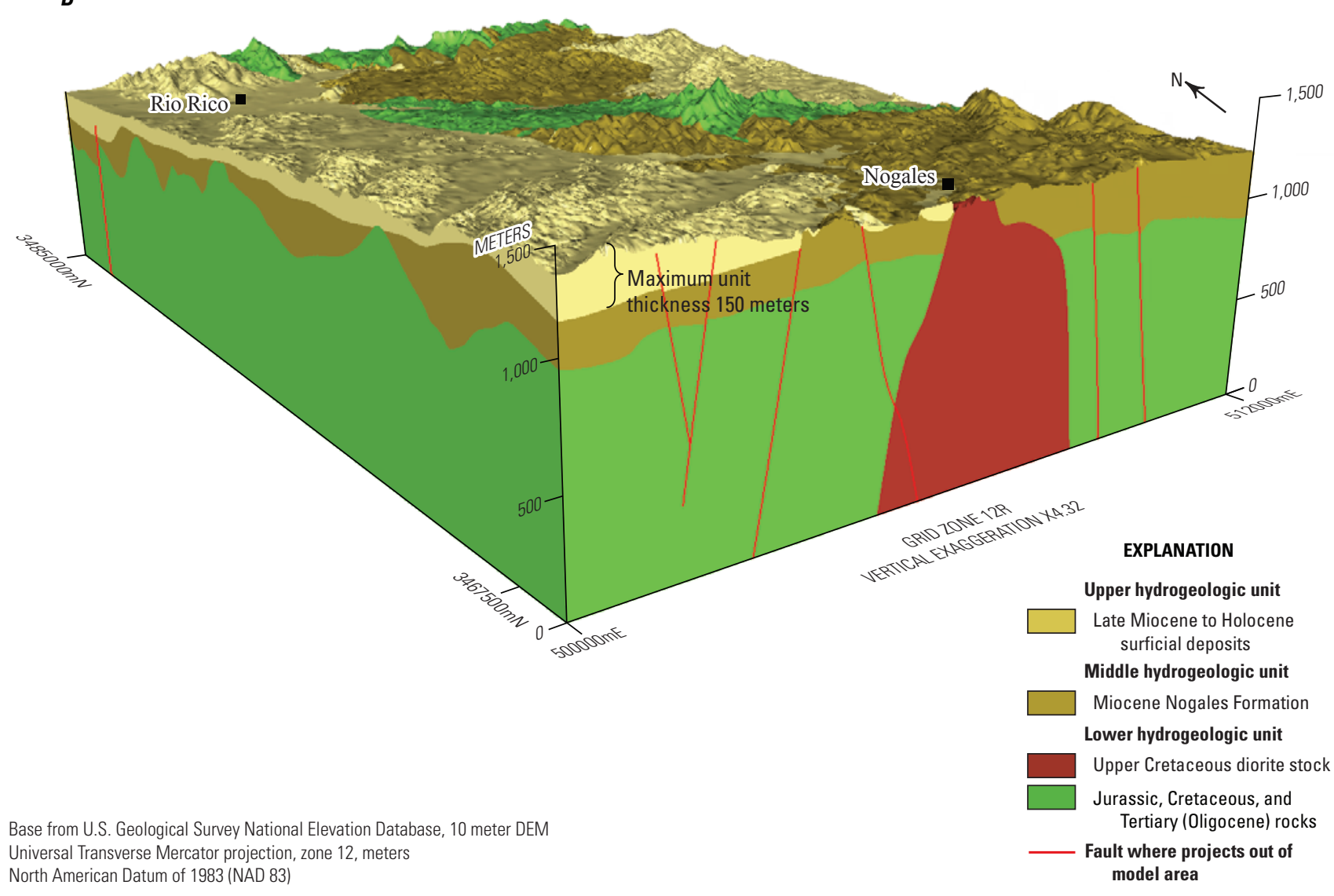

Figure 18. $A$, view to the southeast of upper hydrogeologic unit. Unit thickness is interpreted to increase to maximum thicknesses of about 150 meters in the Rio Rico area, at northwestern model edge. $B$, view to the northeast of the upper hydrogeologic unit. The unit attains maximum thicknesses of about 150 meters in the southwestern part of the model, where the basin-fill deposits become proximal to the Atascosa Mountains (fig. 1), the source terrain for these deposits. 

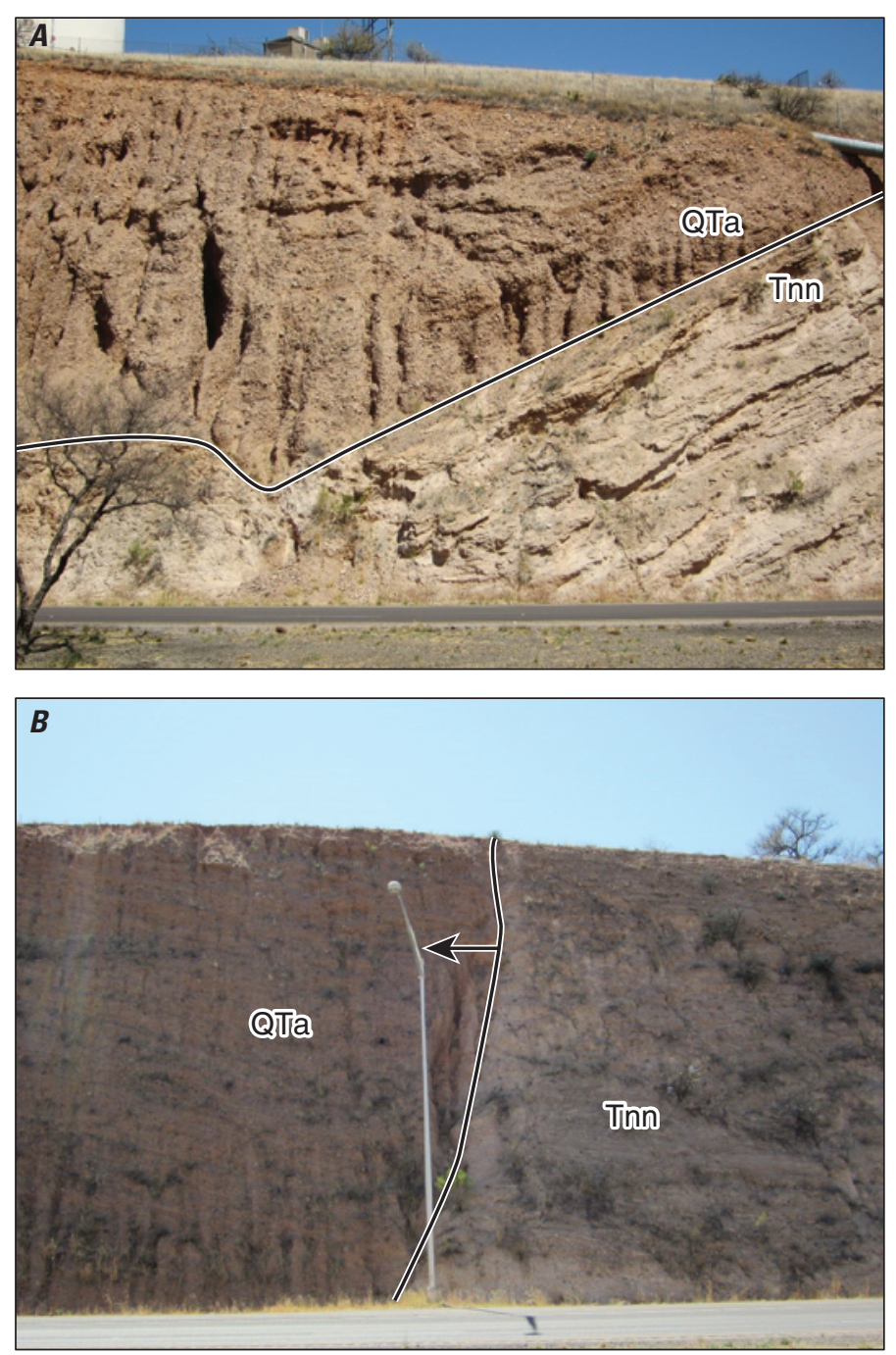

Figure 19. $A$, view to the east of reddish-brown late Miocene to early Pleistocene basin-fill deposits (QTa) unconformably overlying Nogales Wash member of the Nogales Formation (Tnn) in a roadcut at Crawford Hill (fig. 2); height of roadcut about 20 meters. $B$, view to the west directly across Interstate 10 from roadcut at Crawford Hill, showing subvertical fault (black line with arrow on downthrown side) juxtaposing sediments of the Nogales Wash Member of Nogales Formation (Tnn) in footwall, against late Miocene to early Pleistocene basin-fill deposits (QTa) in hanging wall; height of outcrop about 18 meters.

The age of basin-fill deposits in the map area is poorly constrained because of the absence of any direct geochronologic age determinations for the unit. A maximum age constraint is provided by the $11.67 \mathrm{Ma}$ age for basaltic intrusive rocks within the underlying Mariposa member of the Nogales Formation. A minimum age constraint cannot be derived in the map area, but the unit underlies a prominent high, very old capping gravel deposit immediately to the north of the study area (see Youberg and Helmick, 2001), which likely correlates with a similar high capping gravel fan deposit in
Sonoita Creek, and constrained to an early Quaternary age (Menges, 1981; Menges and McFadden, 1981). These relations provide a general late Miocene to early Pleistocene age for basin-fill deposits, which most likely is concentrated in late Miocene to Pliocene time. This age assignment is consistent with the estimated age ranges for the majority of basinfill deposits observed in southeastern Arizona (Menges and Pearthree, 1989).

\section{Early Pleistocene to Holocene Alluvium}

Early Pleistocene to Holocene alluvium consists of 15 surficial geologic map units shown and described in Page and others (2016b); these are younger than the late Miocene to early Pleistocene basin-fill deposits (map unit QTa), and overlie the older basin-fill deposits, and some basement units. These units are mostly exposed along the modern-day Santa Cruz River inner valley, and along the major tributaries of Sonoita Creek and Nogales Wash.

Early Pleistocene to Holocene units in the area comprise a relatively thin series of alluvial deposits associated with both piedmont alluvial fans and discrete channelized drainages, which initially developed in the early Pleistocene and have continued to form into modern time. The primary drainage in the model area is the Santa Cruz River, which forms an axial drainage joined by two major tributary drainages, lower Sonoita Creek and lower Nogales Wash. These tributaries drain substantial areas outside of the study area, as well as numerous smaller intrabasin tributaries that are spatially restricted to a given basin side slope and, for the larger tributaries, the adjoining basement highland source areas.

Each of the drainages in this system contains a meandering channel belt, comprising multiple braided to anastomosing subchannels and bars, which are flanked by undissected floodplains and low terraces. Some smaller tributaries locally contain small alluvial fans interspersed between the dominant channelized reaches. These central drainage lowlands are flanked by dissected valley side slopes that are underlain by mostly pre-Quaternary deposits of basin-fill deposits and (or) older sedimentary and basement units. These valley side slopes commonly contain eroded and dissected topographic benches associated with thin underlying terrace or fan gravel, inset into the subjacent mostly pre-Quaternary substrate. These terrace surfaces and deposits record a suite of successively older and higher former levels, ranging in age from early Holocene to middle Pleistocene, that were produced within local depositional intervals during the progressive long-term downcutting of the valley drainages. The interfluve areas between the incised tributary valleys within the basin piedmonts are characterized by narrowly rounded ridge crests, developed on the mostly pre-Quaternary substrate, but locally are capped by thin early to middle Pleistocene fan deposits.

Quaternary alluvium typically consists of poorly to moderately bedded, unconsolidated, poorly sorted sandy gravel to gravelly sand. The gravel components are subrounded, rounded, to subangular, with pebble, cobble, and local small 
boulder textures. A given deposit is commonly associated with a geomorphic surface characterized by a suite of definable parameters related to (a) progressive alteration and modification of the original depositional surface, such as internal dissection, and pavement development, (b) development of varnishing and physical weathering of surface clasts, and (c) formation of surface soils. Each of these parameters change with time, and thus they can be used for both unit correlations across the model area and assigning at least general age ranges for each unit. Surface heights above adjacent modern channels provide additional constraints for correlations and age relations of terraces and fans in dissected terrains.

\section{Hydraulic Properties of Late Miocene to Early Pleistocene Basin-Fill Deposits, and Early Pleistocene to Holocene Alluvium}

Thickness of the late Miocene to early Pleistocene basin-fill deposits in the Rio Rico and Nogales 7.5' quadrangles ranges from 50 to $150 \mathrm{~m}$ (Page and others, 2016b). Gettings and Houser (1997) reported similar thicknesses for the unit in the Rio Rico area of about $150 \mathrm{~m}$, but they reported thicknesses of the unit to the north in the Tubac area at about $100 \mathrm{~m}$, and thicknesses of about $250 \mathrm{~m}$ for the unit farther to the north in the Amado area. Nelson (2007) reported hydraulic conductivity values for the basin fill based on aquifer tests which ranged from 1 to $30 \mathrm{ft} / \mathrm{d}$ based on aquifer tests. Extremely high hydraulic conductivity values (200 to 2,000 ft/d for the unit were noted northwest of the study area, in Peck Canyon (fig. 1), where the high hydraulic conductivity values were interpreted to be associated with a fault zone (Nelson, 2007). New geologic mapping by the authors confirmed a major range-front-fault exposed in the Peck Canyon area (fig. 1). The fault downdrops thick sections of late Miocene to early Pleistocene basin-fill deposits in the hanging wall, against highly fractured Tertiary volcanic rocks in the footwall.

Thickness of individual units which make up the early Pleistocene to Holocene alluvium generally range from 1 to $3 \mathrm{~m}$, and maximum composite thicknesses for the unit are estimated at about $30 \mathrm{~m}$ based on mapping by Page and others (2016b). Clear Creek Associates (2011) reported composite thicknesses of 12 to $30 \mathrm{~m}$ for the unit along the Santa Cruz River, near Guevavi Canyon (fig. 2). The early Pleistocene to Holocene alluvial deposits are productive aquifers in the basin partly because of their deposition in broad, continuous river channel belts, traversing the inner valley of the Santa Cruz River and its major tributaries. Early Pleistocene to Holocene alluvium in the upper Santa Cruz Basin generally has high hydraulic conductivity values, and Nelson (2007) reported mean values of about $600 \mathrm{ft} / \mathrm{d}$ from aquifer tests in the Rio Rico area within the model area. Farther north in the Tubac and Amado areas, hydraulic conductivity mean values were lower than the Rio Rico area, at about $170 \mathrm{ft} / \mathrm{d}$ (Nelson, 2007), and independent modeling studies in that area reported a range in mean values from 100 to $150 \mathrm{ft} / \mathrm{d}$ (Hanson and Benedict,
1994; Mason and Bota, 2006). Early Pleistocene to Holocene alluvium is the main aquifer along the Santa Cruz River (Erwin, 2007), south of Rio Rico and north of the international border. Although wells in the alluvium in this area are some of the most productive wells for the city of Nogales, these wells are reported to only have high production rates for limited amounts of time because of lack of storage and decreases in annual recharge (Erwin, 2007). Aquifer tests from wells in the unit in the Guevavi Canyon area (fig. 2) indicated extremely high transmissivities (Erwin, 2007). Surface outcrops of the Nogales Formation are present near the location of the aquifer tests; it is possible some of these wells penetrate and are screened in the Nogales Formation below the alluvium (Clear Creek Associates, 2011), and the high transmissivities may reflect composite values attained from Quaternary alluvium and highly fractured Nogales Formation below.

\section{Basin Structure}

All major mapped faults in the study area are included in the 3D model (fig. 20), and of those, only the primary ones are discussed in this section. Abundant fracture zones in the Miocene Nogales Formation are noted in the Nogales area, and these fractures are related to the faults which formed as extensional structures during major episodes of Tertiary extensional deformation in the region. Faults and fractures in basin sediments of the Nogales Formation are believed to have significant effect on groundwater flow in the upper Santa Cruz Basin (Page and others, 2016a), because although many of the sediments in the formation have characteristics indicating they may be productive aquifers based only on porous-media flow, faulting and fracturing may further enhance permeability and groundwater flow in the basin aquifers by orders of magnitude.

Faults in the 3D model were defined by surface geologic mapping by Page and others (2016b), Drewes (1980), and Simons (1974), and other concealed faults, especially in the western part of the model area, were mapped based on interpretation of geophysical data (Bultman and Page, 2016). Most faults in the study area (figs. 2 and 20) formed during Miocene extensional deformation, and main episodes of extension occurred in southern Arizona from about 20 to $10 \mathrm{Ma}$ (Menges, 1981; Menges and McFadden, 1981; Menges and Pearthree, 1989). Extensional deformation was broadly contemporaneous with deposition of the Nogales Formation, based on observations that all members of the formation are moderately to highly faulted, with abundant intraformational faults and fractures (figs. 13, 14, 16, 17, and 19), and moderate to steeply inclined bedding dips (fig. 14). Extensional faulting lasted until latest Miocene time in the area based on faults, which cut only the oldest post-Nogales Formation late Miocene basin-fill deposits; Pliocene through Holocene deposits are undeformed.

The main structural feature in the area is the Mount Benedict horst block (figs. 2, 6, and 7), a triangular zone of 


\section{EXPLANATION}

QTa Late Miocene to Holocene surficial deposits

Nogales Formation (Miocene)

\begin{tabular}{|l|l}
\hline Tnm & Mariposa member \\
\hline Tnn & Nogales Wash member \\
\hline Tnp & Proto Canyon member \\
\hline
\end{tabular}

$\mathrm{Tg}$ Grosvenor Hills Volcanics (Oligocene)

Diorite stock (Upper Cretaceous)

Ks Salero Formation (Upper Cretaceous)

Quartz Monzonite of Mount Benedict (Jurassic)

$\mathrm{Jb}$ Biotite-hornblende quartz monzonite

$\mathrm{Jbm}$ Quartz monzonite

Upper hydrogeologic unit

Late Miocene to Holocene surficial deposits

Middle hydrogeologic unit

Miocene Nogales Formation

Lower hydrogeologic unit

Jurassic, Cretaceous, and Tertiary (Oligocene) rocks

i Normal fault-Ball and bar on downthrow block

Fault where projects out of model area

Base from US. Geological Survey National Elevation Database, 10 meter DEM

Universal Transverse Mercator projection, zone 12, meters

North American Datum of 1983 (NAD 83)

Figure 20. Geologic map of Page and others (2016b) draped over digital elevation model, showing major faults and a complex graben included in the three-dimensional model. 
uplifted Jurassic Quartz Monzonite of Mount Benedict and overlying members of the Nogales Formation. The horst block is important to the hydrogeologic framework, because it forms an uplifted basement confining unit, which separates the southern upper Santa Cruz Basin into two groundwater basins, one to the east of the horst block and Santa Cruz River, and south of the Grosvenor Hills, and the other to the west of the horst block, and Nogales Wash (figs. 21 and 22). These major basins are further subdivided into subbasins defined by Bultman and Page (2016), which are discussed in the Geophysical Data section of this report. The major fault in the study area is the Mount Benedict fault, which bounds the east side of the horst block (figs. 2, 3, 20, and 21). The west side of the horst block is bound by several north- to northwest-striking faults which progressively downdrop Jurassic monzonite and Miocene Nogales Formation rocks westward into the subsurface (fig. 2). These faults include the Grand Avenue fault, and several concealed faults to the west (figs. 2 and 20), mapped based primarily on geophysical data (Bultman and Page, 2016; Page and others, 2016b).

The northwest-striking Mount Benedict fault (Gettings and Houser, 1997; Page and others, 2016b) is the major fault in the study area (figs. 2, 20, and 21). The fault extends across the entire model area, and is not offset by other faults. The fault is mostly concealed by surficial deposits along the Santa Cruz River (Page and others, 2016b), and it controls the course of the river from the Rio Rico area, southward to across the international border and into Sonora, Mexico. Surface exposures of the fault are northeast of the Santa Cruz River, northwest of Guevavi Canyon, and southeast of Sonoita Creek, where the fault plane strikes about $\mathrm{N} 40^{\circ} \mathrm{W}$ and dips about $65^{\circ}$ northeast (Page and others, 2016b). In this

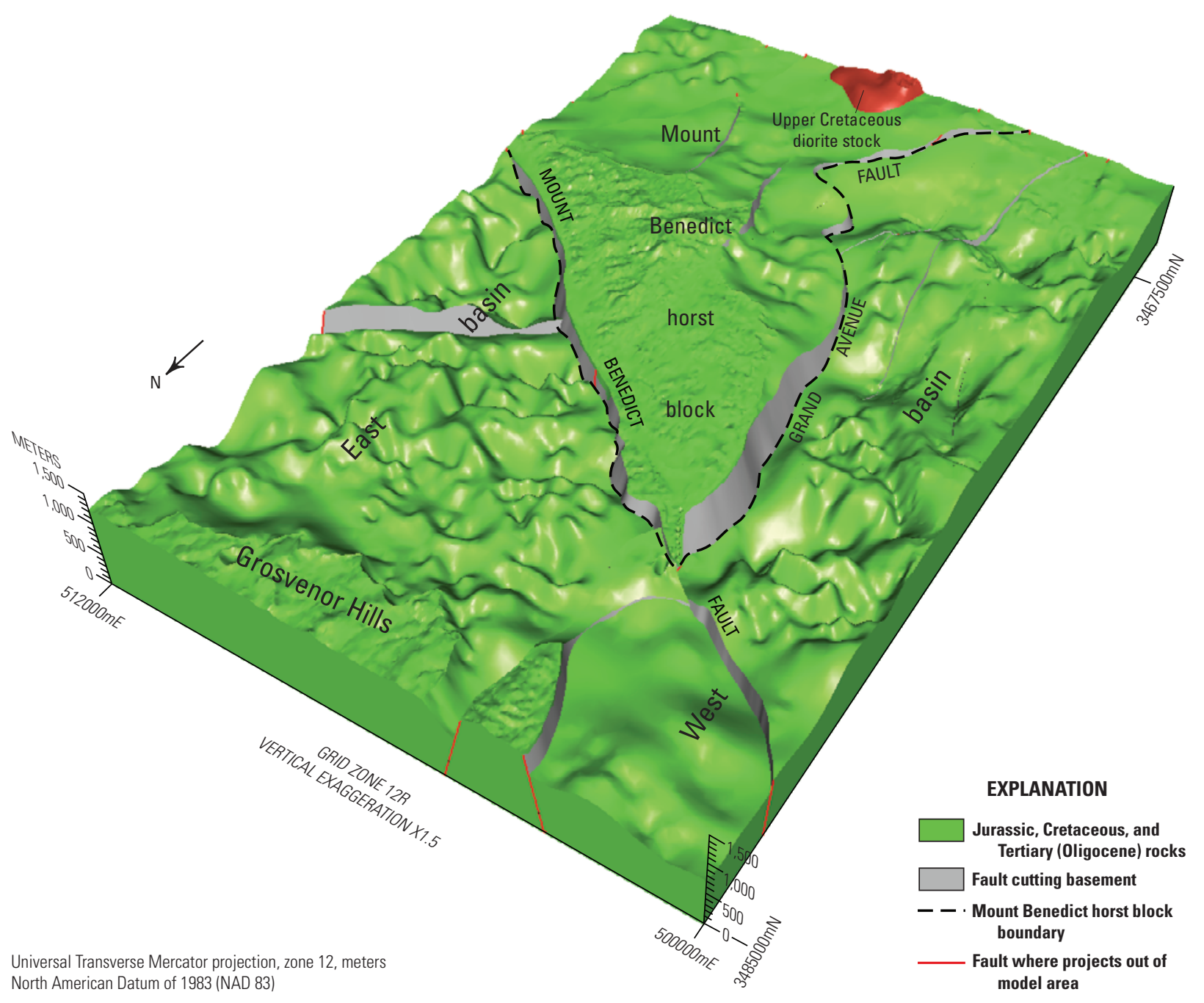

Figure 21. Southeast view of top of basement surface showing Mount Benedict horst block separating this part of the upper Santa Cruz basin into two groundwater basins, one to the east (East basin), and the other to the west (West basin) of the horst block. 
area, the fault downdrops sediments of the Mariposa member of the Nogales Formation against the Quartz Monzonite of Mount Benedict and also some Salero Formation, which unconformably overlies the monzonite locally. Other known exposures of the fault in the area are in the adjacent Cumero Canyon quadrangle, southeast of the intersection of State Highway 82 and the Santa Cruz River (fig. 1). In this area, the fault juxtaposes red arkosic conglomerate of the Proto Canyon member of the Nogales Formation in the footwall against pinkish- to yellowish-gray volcaniclastic sandstone of the Mariposa member in the hanging wall. Like many other extensional faults in the Basin and Range Province, the northwest-striking Mount Benedict fault is likely a reactivated older structure that had a long complex history; northwest-striking faults formed in the region during the Mesoproterozoic, Late Triassic, and late Miocene Basin and Range extension (Drewes, 1980).

The Grand Avenue fault (figs. 2, 20, and 21) bounds the west side of the Mount Benedict horst block, and is concealed along much of its trace (Page and others, 2016b). At its southern end, the fault strikes northeast and is concealed in Ephraim Canyon (fig. 2); north of the canyon, the fault is concealed, but it separates isolated outcrops of the Mariposa member of the Nogales Formation on the downthrown side from rocks of the Nogales Wash member on the upthrown side (Page and others, 2016b). The fault is exposed south of Mariposa Road and west of Grand Avenue (fig. 2), where it strikes about $\mathrm{N} 30^{\circ} \mathrm{E}$ and dips $60^{\circ}$ northwest and juxtaposes massive claystone of the Mariposa member in the hanging wall against volcaniclastic sandstone of the Nogales Wash member in the footwall. North of Mariposa Road, the fault bends northwestward (figs. 2 and 20), and juxtaposes volcaniclastic sandstone and conglomerate of the Mariposa member in the hanging wall against volcaniclastic sandstone of the Proto Canyon member in the footwall. The northernmost exposures of the fault are near the juncture of Potrero Canyon and Interstate 19 (fig. 2). Here, the fault downdrops late Miocene to early Pleistocene basin-fill deposits in the hanging wall, against tuffaceous sandstone in the middle part of the Proto Canyon member of the Nogales Formation in the footwall. Farther north, the Grand Avenue fault is concealed, and hanging wall rocks of the Mariposa and Proto Canyon members in the subsurface are interpreted (based on geophysical modeling) to be progressively downdropped northward against the Quartz Monzonite of Mount Benedict in the footwall, indicating significant west-side down offset (Page and others, 2016a). At its northern end, the Grand Avenue fault terminates at the Mount Benedict fault (Page and others, 2016a; figs. 2 and 20). Several other faults are mapped west of the Grand Avenue fault (figs. 2 and 20); these faults are concealed and were interpreted based on airborne transient electromagnetic data and other geophysical data (Bultman and Page, 2016). The Grand Avenue fault and faults to the west together form a complex graben in the subsurface of the western part of the model area (figs. 2 and 20); this fault system may be important in affecting northward groundwater flow in deeper parts of the Nogales Wash basin, from the south in Mexico, northward into the Rio Rico area.

The Patagonia fault (Simons, 1974; Bultman, 2015) is a concealed northeast-trending fault in the northeast part of the study area (fig. 20). The fault is down to the northwest, based on outcrops east of the study area, consisting of Cretaceous Salero Formation on the northwest side of the fault, and Proterozoic quartz monzonite outcrops on the southeast side. This fault, and other concealed northeast-trending faults to the northwest of the Patagonia fault, and mapped by Page and others (2016b), may be important in affecting groundwater flow from mountain front recharge areas along the Grosvenor Hills and Patagonia Mountains, eastward into the Santa Cruz River inner river valley. From the inner valley, the groundwater is then diverted northwestward into the Rio Rico area, as it flows along the uplifted monzonite confining unit of the Mount Benedict horst block. These observations are consistent with Nelson (2007), who reported potentiometric surface contour maps indicating lateral flow from these mountain front recharge areas into the Santa Cruz River valley axis.

The Proto Canyon and Yerba Buena Canyon faults are two northeast-striking faults in the southeastern part of the study area (figs. 2 and 20). These faults are both interpreted to terminate into the northwest-striking Mount Benedict (fig. 2). The Proto Canyon fault parallels Proto Canyon along State Highway 82 (fig. 2), where it strikes about $\mathrm{N} 45^{\circ} \mathrm{E}$ and dips southeast, and offsets rocks in the lower part of the Proto Canyon member (Page and others, 2016b). In the Proto Canyon area, the fault downdrops cliff forming, cyclic units in the middle part of the member in the hanging wall, against arkosic conglomerate and sandstone in the lower parts of the Proto Canyon member in the footwall. From Proto Canyon northeastward, the fault eventually cuts out the arkosic units, and downdrops the cyclic, cliff-forming units of the lower part of the Proto Canyon member against the Quartz Monzonite of Mount Benedict near the eastern edge of the 3D-model area near the Santa Cruz River (Page and others, 2016b). The southern segment of the Proto Canyon fault offsets rocks mostly of the Nogales Wash and Mariposa members of the Nogales Formation, and it extends southward into Mexico. The Yerba Buena Canyon fault (fig. 2) is subparallel to the Proto Canyon fault, and is also down to the southeast. Like the Proto Canyon fault, it offsets units mostly of the Proto Canyon member along its northern segment, and offsets the Mariposa and Nogales Wash members along its southern segment, where it extends southward into Mexico (Page and others, 2016b).

In the northwestern part of the model area, faults bound the west and east flanks of the San Cayetano Mountains to form a horst block (figs. 2 and 20). The Rio Rico fault (figs. 2 and 20) is the range-front fault on the west flank of the San Cayetano Mountains, and is down-to-the-west where it forms the eastern margin of the Rio Rico subbasin of Gettings and Houser (1997). The fault is exposed at several locations; at the southernmost location, the fault juxtaposes post-Nogales Formation basin fill in the hanging wall against rocks of the 
Salero Formation in the footwall, and strikes about N $35^{\circ} \mathrm{W}$ and dips $70^{\circ}$ southwest (Page and others, 2016b). Northward along the Rio Rico fault, Tertiary rhyolitic intrusive rocks in the hanging wall are juxtaposed against mostly sedimentary rocks of the Salero Formation in the footwall; these latter rocks compose most of the high ridge of the San Cayetano Mountains. The Rio Rico fault forms the eastern edge of a graben system referred to as the Santa Cruz graben (Drewes, 1980), which tectonically controls the Santa Cruz Basin in this area.

The San Cayetano fault of Drewes (1972) bounds the east flank of the San Cayetano Mountains (figs. 2 and 20), and is down-to-the-east and it offsets rocks of the Proto Canyon member of the Nogales Formation and Grosvenor Hills Volcanics in the hanging wall against the Salero Formation in the footwall (Page and others, 2016b). North of the study area, the fault offsets Grosvenor Hills Volcanics in the hanging wall against the Salero Formation in the footwall, where Drewes (1972) estimated about 300 to $760 \mathrm{~m}$ of vertical displacement along the fault. Drewes (1972) reported this displacement was likely cumulative over a period of time following late Oligocene volcanism to after deposition of the Miocene Nogales Formation. South of the San Cayetano Mountains and Sonoita Creek, the San Cayetano fault offsets rocks mostly of the Mariposa member of the Nogales Formation, and then it terminates against the Mount Benedict fault (Page and others, 2016b). The San Cayetano fault may be important in providing mountain recharge from the Grosvenor Hills southward into the Sonoita Creek drainage basin, and eventually westward into the Santa Cruz River inner valley. Nelson (2007) reported flow data collected in the Sonoita Creek area indicating subsurface flow between the Fresno Canyon-Sonoita Creek confluence (fig. 2) and the Santa Cruz River, and estimated underflow rates of at least 500 acre-feet per year.

\section{Miocene to Holocene Development of the Upper Santa Cruz Basin in the Study Area}

The geologic units that make up the upper Santa Cruz Basin aquifer system include the Miocene Nogales Formation in the lower part, and the late Miocene to early Pleistocene basin-fill deposits and early Pleistocene to Holocene alluvium combined in the upper part. The basin geometry is complex because basin sediments were deposited onto a highly irregular basement erosion surface, which underlies and predates the Nogales Formation (fig. 6). Basement units were deformed by episodes of Miocene Basin and Range extension in addition to older pre-Tertiary deformational events, most notably Cretaceous plutonism and faulting related to the Laramide orogeny (Simons, 1974).

Initial development of the upper Santa Cruz Basin began during early Miocene time, with faulting at the basin margins, and subsequent deposition of sediments of the Proto Canyon member (fig. 22), the lowest member of the Nogales Formation (fig. 4). Page and others (2016b) reported the maximum ages of the Nogales Formation at about 20 to $18 \mathrm{Ma}$ in the basin; these ages are based on ${ }^{40} \mathrm{Ar} /{ }^{39} \mathrm{Ar}$ geochronology on four plagioclase grains (Cosca and others, 2013) from a rhyolite tuff in the Agua Fria Canyon area (fig. 1), where the tuff is exposed near the base of the formation. These are the oldest dates for the formation in the region. In the southern part of the upper Santa Cruz Basin, sediments of the Proto Canyon member were deposited in an area coincident with the modern-day basin. During deposition of the Proto Canyon member, the Mount Benedict area (fig. 2) was likely a paleotopographic high near the center of the basin, based on coarse debris-flow conglomerate at the base of the member, which was initially shed off the flanks of Mount Benedict (fig. 22D). Uplift of the Mount Benedict horst block occurred during and (or) following deposition of the Proto Canyon member to expose the basal debris-flow conglomerate, and to further compartmentalize the southern part of the upper Santa Cruz Basin into two main basins - one is west of the horst block and the Grand Avenue fault, and the other is east of the horst block, and the Mount Benedict fault, and south of the Grosvenor Hills (figs. 21 and 22). Following deposition of the Proto Canyon member, sediments of the Nogales Wash member were locally deposited during the middle Miocene in the southern part of the model area (figs. 20 and 22). Distribution of the member combined with onlapping relations with the lower Proto Canyon member indicate Nogales Wash member sediments were deposited in a paleodrainage area eroded into the Proto Canyon member, coincident with the modern-day Nogales Wash (Page and others, 2016b). In middle to late Miocene time, following deposition of the Nogales Wash member, sediments of the Mariposa member were deposited (figs. 3 and 4), and these sediments represent the final infilling of the Miocene Nogales Formation depositional basin. Further faulting and uplift of the horst block continued throughout and following deposition of the Mariposa member based on the observation that all members of the Nogales Formation are fractured and faulted, and the major faults cut the oldest part of late Miocene basin-fill deposits which postdate the Nogales Formation, and Pliocene through Holocene sediments are generally undeformed. The minimum age of the Nogales Formation is about $11 \mathrm{Ma}$, based on ${ }^{40} \mathrm{Ar} /{ }^{39} \mathrm{Ar}$ geochronology (whole rock) determined for a basalt in the Mariposa member (Page and others, 2016b; Cosca and others, 2013).

Following development of the Nogales depositional basin, and beginning during latest Miocene time, late Miocene to early Pleistocene basin-fill sediments were deposited above the exhumed and deformed Nogales Formation basin sediments (fig. 22A); this relation is demonstrated by the unconformable to disconformable contact between the Nogales Formation and overlying basin-fill deposits in the study area (fig. 19A). Late Miocene to early Pleistocene basin-fill deposits in the region represent the exposed uppermost and youngest sections of primary alluvial-fan deposits that filled these late 
A late Miocene to present

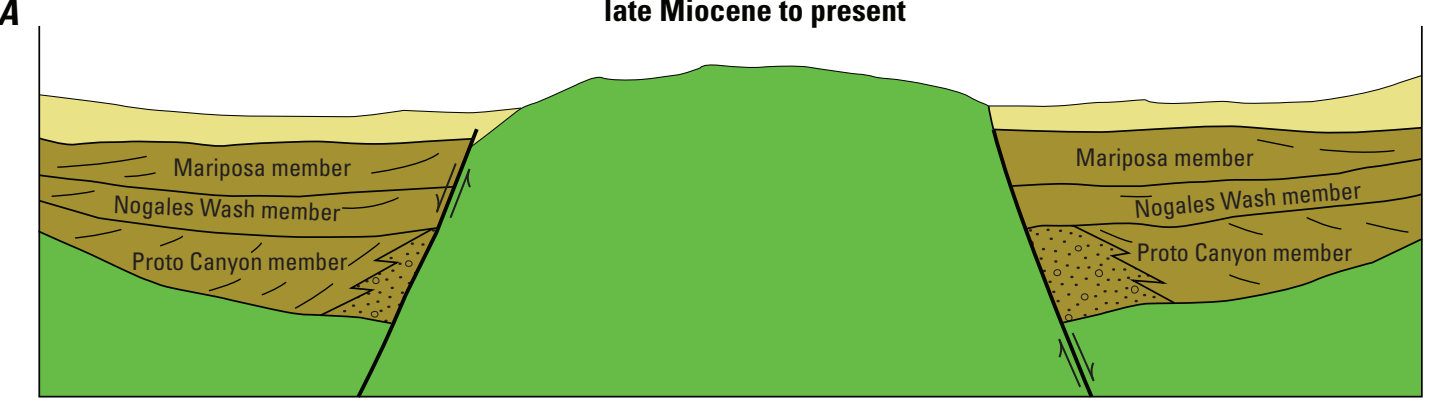

B

middle to late Miocene
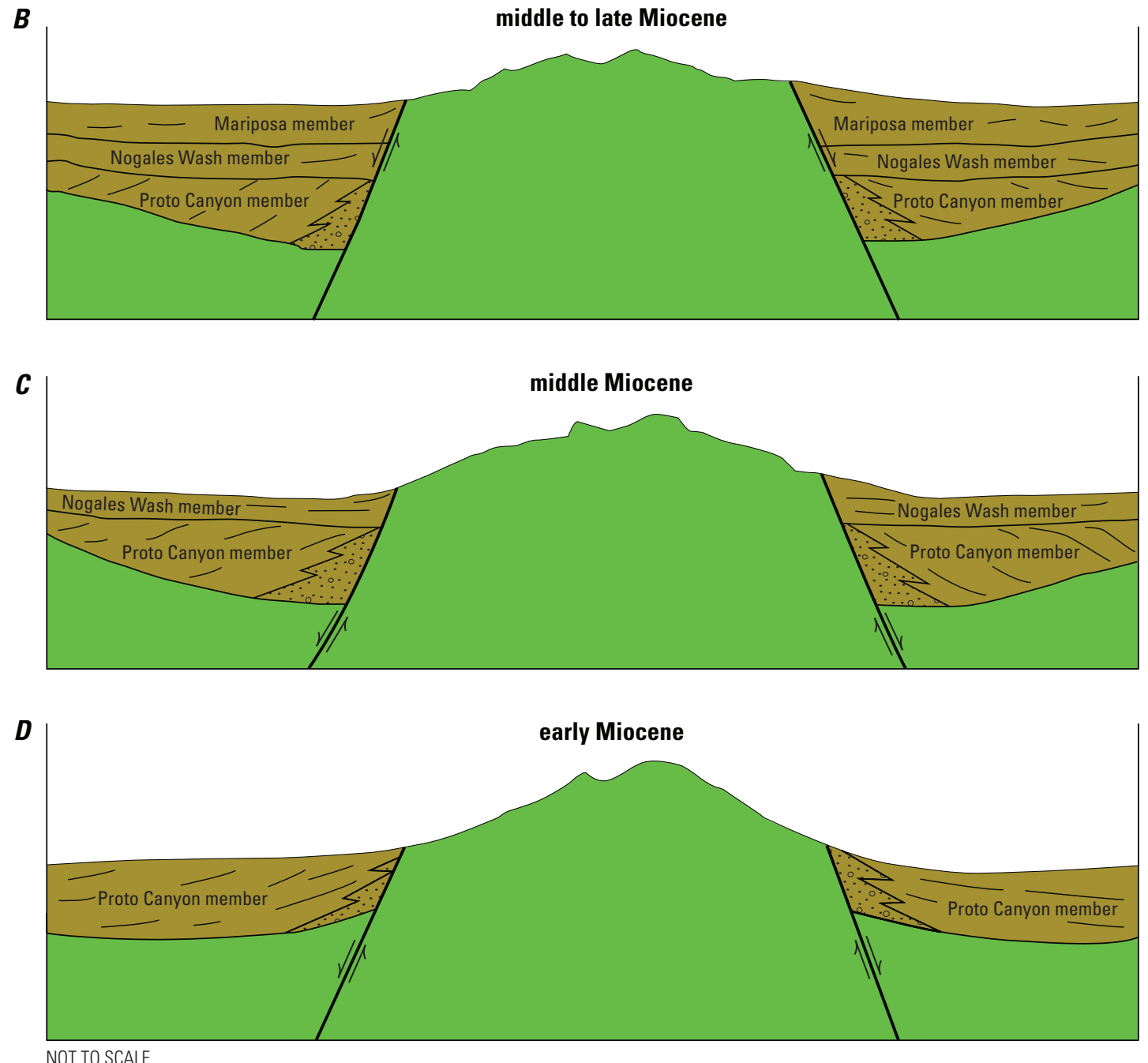

\section{EXPLANATION}

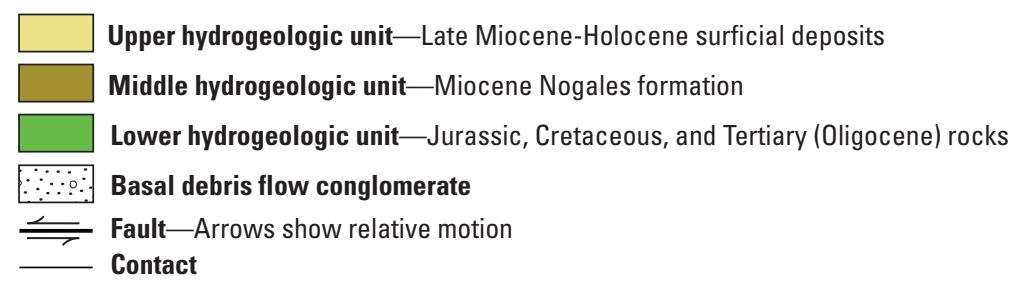

Figure 22. Diagrammatic east-west oriented sections across the Mount Benedict horst block, showing the sequential development of the southern upper Santa Cruz Basin from early Miocene to present. $A$, deposition of late Miocene to Holocene surficial deposits above exhumed and deformed Nogales Formation sediments. $B$, middle to late Miocene deposition of the Mariposa member of the Nogales Formation. $C$, middle Miocene deposition of the Nogales Wash member of the Nogales Formation. $D$, early Miocene deposition of the Proto Canyon member of the Nogales Formation, including debris-flow conglomerate shed off flanks of Mount Benedict horst block. 
Miocene to early Pleistocene depositional basins, and which are concordant with the modern system of physiographic basins and ranges in the study area. These deposits typically form a sedimentary veneer with thicknesses estimated to be 50 to $150 \mathrm{~m}$, and they unconformably overlie older rocks in the area, including the Nogales Formation and a variety of basement units.

The final phase of upper Santa Cruz Basin development includes deposition of early Pleistocene to Holocene alluvium, which Page and others (2016b) broke out into 15 surficial geologic map units. These deposits comprise a relatively thin series of alluvial deposits associated with both piedmont alluvial fans and axial streams and their major tributaries of the Santa Cruz River system, which initially developed during the early Pleistocene and have continued to form into modern time. These deposits are associated with and are controlled by a linked system of local drainages that are tributaries to the master axial drainage of the upper Santa Cruz River. The river in turn extends far above and below the reach within the 3D-model area, and ultimately is externally integrated downstream into the Gila River and lower Colorado River regional drainage basins. The final phases of internal basin aggradation recorded by the highest stratigraphic and physiographic levels of the early Pleistocene to Holocene alluvial deposits probably ended sometime prior to the initial formation of the oldest and highest capping alluvial fan deposits of probable early Quaternary age, based on regional correlations with similar deposits in surrounding areas (Menges and McFadden, 1981; Menges and Pearthree, 1989). Whether these earliest Quaternary fan deposits were associated with an externally drained ancestral Santa Cruz River system cannot be determined from relations in the area. Regardless, the suite of progressively younger and lower inset terrace-fan deposits indicate linkage to a continually downcutting drainage controlled by incision of an externally draining Santa Cruz River.

\section{Data for Construction of the Three- Dimensional Hydrogeologic Model}

\section{Geologic Map, Cross Sections, and Digital Elevation Data}

The geologic map data for the 3D hydrogeologic model is based on the geologic map of the Rio Rico and Nogales 7.5' quadrangles (Page and others, 2016b; https://pubs.er.usgs.gov/ publication/sim3354). Geology in the Rio Rico and Nogales 7.5' quadrangles was compiled in ArcMap (version 9.3.1), with the aid of 2010 National Agriculture Imagery Program (NAIP) orthophotography, imagery viewed with Google Earth, 1996 National Aerial Photography Program (NAPP) 1:40,000scale color infrared aerial photographs, and 1:24,000- and 1:100,000-scale topographic maps. The geologic map report includes six cross sections, which are shown in sheet 2 of 2 in Page and others (2016b; https://pubs.usgs.gov/sim/3354/ sim3354_sheet2.pdf). The sections are generally oriented east-west, perpendicular to the major structures in the model area. The base of the Miocene Nogales Formation and (or) top of the basement unit in the sections was interpreted primarily from surface geology on the map and the cross sections, but was supplemented by geophysical modeling data in areas where subsurface data were sparse or nonexistent. Figure 3 shows the geologic map draped over the digital elevation model (DEM) at the top of the model. The DEM was obtained from the U.S. Geological Survey (USGS) National Elevation Dataset (NED), a primary elevation data product of the USGS (https://eros.usgs.gov/elevation-products).

Previous groundwater models for the upper Santa Cruz Basin used the published geologic maps by Simons (1974) and Drewes (1980). Page and others (2016b) compiled most of the basement units from the maps of Simons (1974) and Drewes (1980), and their mapping was field checked for accuracy prior to our final compilation. However, these regional-scale maps lack the detail for the Miocene Nogales Formation and late Miocene to Holocene surficial deposits, which are aquifers in the basin. To address this disparity, Page and others (2016b) completed new detailed 1:24,000-scale geologic mapping which resulted in significant refinement of the stratigraphy and structure of the Nogales Formation, the late Tertiary to early Pleistocene basin-fill deposits, and Quaternary alluvial units in the basin.

The new surficial geologic mapping was completed and compiled from interpretation of stereoscopic pairs of 1996 NAPP color-infrared aerial photography (1:40,000 scale), 2010 NAIP orthophotography, imagery viewed with Google Earth, topographic data, and digital soils data (U.S. Department of Agriculture Natural Resources Conservation Service, 2008), using previous mapping in adjacent areas by Youberg and Helmick (2001) and Helmick (1986) as a guide. The surficial geology was mapped on the NAIP imagery using ArcMap Geographic Information System software. Interpretive mapping was constrained by, and unit description and age estimates are based on data collected at Global Positioning System-located field stations along a series of traverses.

\section{Geophysical Data}

Geophysical data were fundamental in the construction of the 3D model, and include (1) Earth's gravity anomaly data from a nationwide database (University of Texas at El Paso, 2013) that was extracted on September 11, 2013; (2) Earth's magnetic field anomaly data from the 1996 Patagonia aeromagnetic survey (Sweeney and Hill, 2001); and (3) data from a 1998 transient electromagnetic survey of the Santa Cruz Basin (Bultman and Page, 2016). These data were used for two purposes. First, the Earth's magnetic field anomaly data were used to construct a depth to basement map (fig. 23) defining the geometry of the top surface of the basement confining unit in the 3D model. Second, all three datasets were used to 


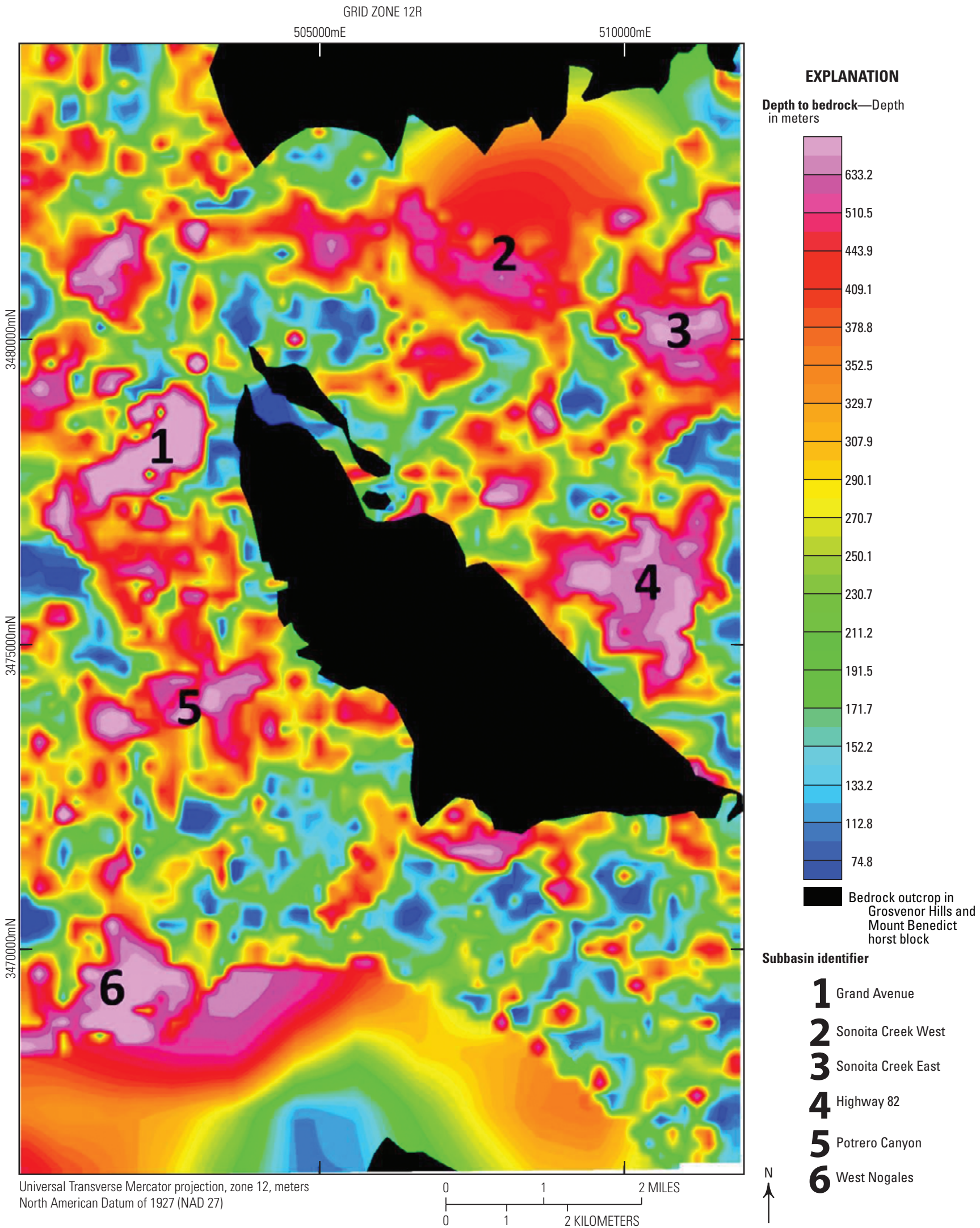

Figure 23. Depth to basement map of Bultman and Page (2016) showing six interpreted subbasins in the 3D-model area. 
define faults and contacts in the basement and Nogales Formation rocks, which are concealed by younger surficial deposits.

\section{Depth to Basement Map}

Gettings and Houser (1997) used the complete Bouguer gravity anomaly data to obtain a map of depth to the top of basement in the upper Santa Cruz Basin. The scarcity of gravity stations in the area meant that the grid from which the map was derived had a 1-km cell size. We used the 1996 Patagonia aeromagnetic survey (Sweeney and Hill, 2001) to produce a depth to basement map (fig. 23) with a higher spatial resolution than the map of Gettings and Houser (1997). These data were collected along east-west flight lines spaced $250 \mathrm{~m}$ apart at a terrain clearance of $230 \mathrm{~m}$ (Sweeney and Hill, 2001). Data were also collected along several widely spaced north-south tie lines that were used to level the flight line data. Earth's magnetic field data acquired by the magnetometer along flight lines are spaced at about 10 meters. To most accurately reflect the flight-line data without making an unmanageably sized grid, these data were gridded at 50-m cell size and decorrugated (Phillips, 2007). This also allows a reasonable number of grid cells (5) for minimum curvature interpolation between flight lines.

Three methods were used to build the depth to basement map based on the aeromagnetic data: Euler deconvolution (Thompson, 1982), horizontal gradient magnitude (Grauch and Cordell, 1985), and analytic signal (Nabighian, 1972, 1974, 1984). Since all methods tend to underestimate the depth to basement (Bultman and Page, 2016), the final depth to basement map was produced by choosing the maximum depth from each of the three methods at a given location and combining all maximum depths.

A problem with using Earth's magnetic field anomaly data to generate a depth to basement map is that many rocks have a natural remnant magnetic field vector not aligned with the direction of the current magnetic field. If this vector points in the opposite direction of the Earth's magnetic field, the rock is said to have a reversed remnant magnetic field. When this is true, solutions for depth to magnetic source rocks can be incorrect. To overcome this problem, the Gettings and Houser (1997) depth to basement model was incorporated into our depth to basement model in regions with rock having known reversed natural remnant magnetic fields (Bultman and Page, 2016). It remains possible that the depth to basement map in the model area may be erroneous in unknown regions of reversed natural remnant magnetism in basement rocks, beneath overlying surficial deposits.

The resulting map (fig. 23) provides a much more detailed description of depth to basement in the upper Santa Cruz Basin study area than the map of Gettings and Houser (1997) and shows the location and geometry of the six deep subbasins. More importantly, the map defines the geometry and thickness of deep subbasins (figs. 23 and 24) containing aquifers in the late Miocene to Holocene surficial deposits, and likely in the Miocene Nogales Formation. The subbasins are about 500 to $800 \mathrm{~m}$ deep, and are up to $1 \mathrm{~km}$ deep in some areas. The subbasins may contain thick sections of fractured Nogales Formation sediments, which we consider as target areas for additional deeper groundwater resources in the upper Santa Cruz Basin (Bultman and Page, 2016; Page and others, 2016a).

Depth to basement estimates based on Earth's magnetic field data can be inaccurate. Mean values of errors in depth estimates to shallow magnetic sources in volcanic rocks (generally less than 100 meters and possibly including rock with reversed natural magnetic remanence), based on methods used here, vary from about 12 to 32 percent but individual estimates can vary dramatically (Casto, 2001).

The accuracy of the depth to basement map produced here is demonstrated using other geophysically based depth interpretations to corroborate the estimates and by geologic relations. For instance, the northern part of the Sonoita Creek West subbasin (fig. 23) is a region of reversed remnant magnetization which produces a large low in the aeromagnetic anomaly map in that region (Bultman and Page, 2016). Therefore, the Gettings and Houser (1997) gravity-based depth to basement model was used there. It is in total agreement with the depth to bedrock map produced here as can be seen from the fact that there is no obvious linear change in depth where the two models meet (fig. 23). The same holds true for the west Nogales subbasin.

Earth's magnetic field-based depths in the Highway 82 subbasin (fig. 23) are much deeper than those seen in the Gettings and Houser (1997) gravity-based depth to basement model (Bultman and Page, 2016). But, there is only one gravity station in the area of the subbasin so the gravitybased depths are not well constrained. In addition, a study by Culbertson and others (2010) using ground-based time-domain electromagnetic methods also predicts a deep subbasin at that location. Additional gravity data in the Highway 82 subbbasin area would better constrain the depth to basement estimates.

While we do not have corroborating data in all locations of the study area, in areas where we have depth estimates based on two or more sets of data, the depth estimates are generally in agreement. This gives us a high confidence in the depth to basement map used here.

\section{Mapping Concealed Faults and Contacts}

Certain functions of potential field data have local extrema over sharp contrasts of rock magnetic intensity (the vector sum of rock magnetic susceptibility and remanence) for magnetic data and rock density for gravity data. Curvature analysis (Blakely and Simpson, 1986) of these functions can be used to locate extrema in the functions and by association the resulting contrast in rock properties. These sharp contrasts in rock properties are inferred to be contacts or faults, and can be observed even when they are in basement buried by nonmagnetic sediments. Two such functions were used here to infer the location of buried faults and contacts with both Earth's magnetic field data and the complete Bouguer anomaly 


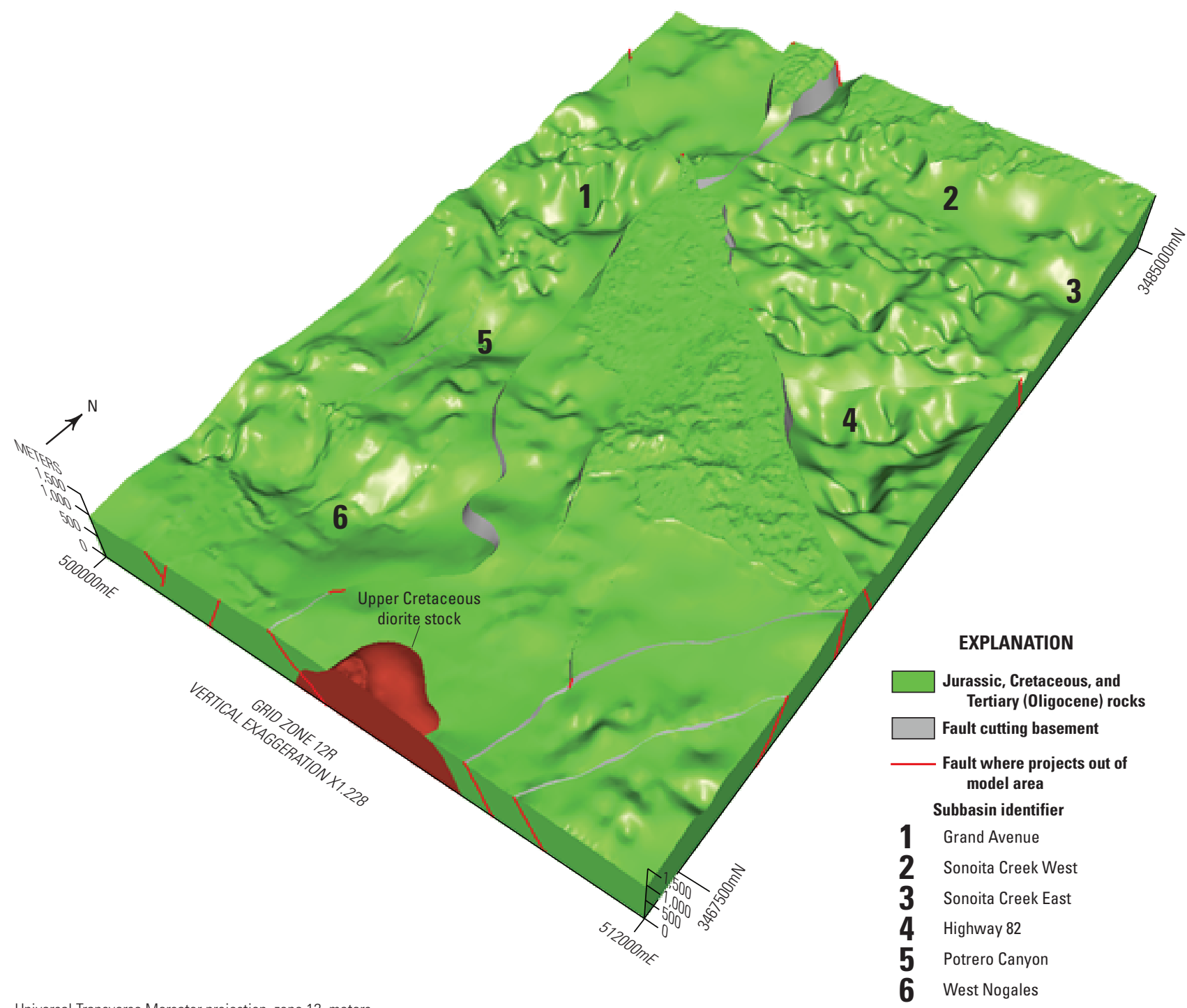

Universal Transverse Mercator projection, zone 12, meters North American Datum of 1983 (NAD 83)

Figure 24. Northwest view of three-dimensional (3D) model showing basement surface (3D model layer 1) and subbasins labeled in figure 23.

data: the horizontal gradient magnitude (Grauch and Cordell, 1985) and the analytic signal (Nabighian, 1972, 1974, 1984). Such ridges that occur in areas of late Pleistocene to Holocene deposits are only inferred to be faults or contacts in the basement beneath if they can be projected from basement outcrop or corroborated by other data. Maps depicting the potential field gradient ridges in the upper Santa Cruz Basin can be found in Bultman and Page (2016).

At the request of the USGS, an electromagnetic survey was flown over parts of south-central Arizona by GeoterrexDighem (now Fugro) from January 8-18, 1998. The survey covered five separate areas and a total of 2,486.9 flight-line kilometers (Bultman and Page, 2016). Of those five separate areas, two lie entirely within the Rio Rico and Nogales 1:24,000-scale quadrangles (areas two and five) and one lies partially within (area four). The data were acquired by
Geoterrex-Dighem using the GEOTEM multicoil system. One product of the GEOTEM system that is provided by the contractor is a conductivity-depth transform (CDT). The CDT is a one-dimensional transform developed by Wolfgram and Karlik (1995) to convert transient electromagnetic data to conductivity in a cross-sectional format for each flight line in the survey. CDTs are based on a horizontal conductor model and generally do a good job of imaging horizontal conductors. While the depth and estimated conductivity may be approximate, the method is sensitive to the extent of these conductors; therefore, it can be very good at identifying breaks and offsets (faults) in horizontal conductors. While there is some uncertainty in the results based on the CDTs, this transform typically works as well as other transform or inversion routines (Vallée and Smith, 2007). 
Interpretations of CDTs were significant in locating faults in basement units and in the Miocene Nogales Formation (Bultman and Page, 2016). Horizontal conductors in many of CDTs show subvertical offsets that are often spatially aligned with gravity or magnetic gradient ridges, and these observations are considered strong evidence for subsurface faults. Offsets in conductors that appear continuously across several adjacent CDTs are interpreted as subsurface faults. All CDTs within the study area are available for download (in TIF and XRL format) from appendix 2 of Bultman and Page (2016).

The geophysical data and interpretations described in this section were the primary source for information on Miocene to Holocene basin depth and subsurface faults on the geologic map of the study area (Page and others, 2016b) and in the 3D model in this report. As such, modeling based on these datasets forms the basis for interpreting most geologic surfaces in the 3D model, including the top of basement (and (or) the base of the Miocene Nogales Formation), the bounding sides of the Upper Cretaceous diorite stock along the southern 3D-model edge, and the faults bounding the major fault blocks in the 3D-model area. Our approach was conservative in interpreting geologic surface boundaries and faults offsetting those boundaries, and as a result, we interpreted faults and surfaces based on the requirement where all three geophysical methods agreed, before a feature was added to the geologic map or 3D model. Also, basin depth estimates based on aeromagnetic data were required not to contradict basement depth information that was visible in the CDTs.

\section{Water Well Data}

We included groundwater elevation point data in the 3D model, which can be loaded and displayed in the 3D Viewer. Most of the data was extracted from the Arizona Department of Water Resources (ADWR) Groundwater Site Inventory database (Arizona Department of Water Resources, 2015) on June 29, 2015. Data from three additional water wells are included (S. Nicely, written commun., 2013); these wells were drilled by the Department of Homeland Security in 2013 and are located along the U.S.-Mexico border. The ADWR database provides the most accurate source of groundwater elevation data in Arizona (Keith Nelson, Arizona Department of Water Resources, written commun., July 1, 2015). For the ADWR wells, the water elevations of wells in the database are sampled at varying time intervals. Wells on the periphery of basins are sampled at intervals of several years, while wells in the central portion of the basin are sampled at much higher frequencies and include key "index" wells that are sampled monthly to quarterly, and about a dozen or so wells that have pressure transducers installed and are sampled four times per day. Wells on the basin periphery were last sampled in 2007 (Keith Nelson, Arizona Department of Water Resources, written commun., July 1, 2015) and wells in the central part of the basin were sampled close to the date of data extraction.

The 3D-model groundwater elevation dataset contains data from 158 water wells extracted from 2015 ADWR
Groundwater Inventory database (ADWR, 2015), and the 3 wells from Department of Homeland Security. The data were entered into an Excel spreadsheet, listing four columns: column 1 includes the ADWR Site ID; columns 2 and 3 include location in Universe Transverse Mercator (UTM), of easting and northing coordinates (zone 12, North American Datum of 1983 [NAD83]), respectively; and column 4 includes water level elevation in meters. The data are available to be loaded in the 3D Viewer in "scattered data (.dat)" file format. The data points are displayed in the model (fig. 25), with the X and $Y$ values representing the UTM easting and northing coordinates, and the groundwater elevation as the " $Z$ " value in meters. In the 3D Viewer program, the user can perform X-, Y-, or Z-axis boundary slicing (see Page, 2018; Demo_3D_ Viewer.pdf) to analyze and identify from which of the three hydrogeologic units the groundwater level elevation measurement was recorded. Caveats for identifying from which unit the water elevation was recorded include the general lack of existing subsurface data for much of the 3D-model area; subsurface hydrogeologic unit elevations were modeled based primarily on geophysical data combined with surface geology, which is currently the best estimate for unit subsurface elevation available. Groundwater elevations in the model dataset range in depth from 1,025 to $1,185 \mathrm{~m}$, and total depth for wells in the model area ranges from about 2 to $300 \mathrm{~m}$. Groundwater elevations decrease from southeast to northwest in the study area, and range from about 1,158 to $1,188 \mathrm{~m}$ in elevation near the U.S.-Mexico border (Erwin, 2007; S. Nicely, written commun., 2013), compared to levels along the Santa Cruz River area in the Rio Rico area which are about 1,005 to $1,036 \mathrm{~m}$ in elevation (Nelson, 2007).

The groundwater elevation dataset is not only applicable to groundwater studies but also is extremely important in addressing security issues along the U.S.-Mexico border. The groundwater elevation data have practical application in mapping the water table, thus identifying an approximate lower depth limit for tunnel excavation, because most discovered tunnels are not excavated below the water table (S. Nicely, written commun., 2013).

\section{Model Construction Methodology}

EarthVision (Dynamic Graphics, Inc.) modeling software was used to create, compile, and display the Rio Rico and Nogales 7.5' quadrangle 3D model, because of the program's ability to model geologic data, while maintaining structural complexity and integrity in three dimensions. The 3D model consists of surfaces that mostly represent unconformities below major hydrogeologic units, boundaries that characterize lateral extents of intrusions, and faults that intersect the hydrogeologic surfaces.

In EarthVision, a 3D geologic model is constructed from geologic surfaces generated from X, Y, and Z scattered data points. For this 3D model, $\mathrm{X}$ and $\mathrm{Y}$ coordinates are UTM, Ellipsoid, Geodetic Reference System 1980 and North 


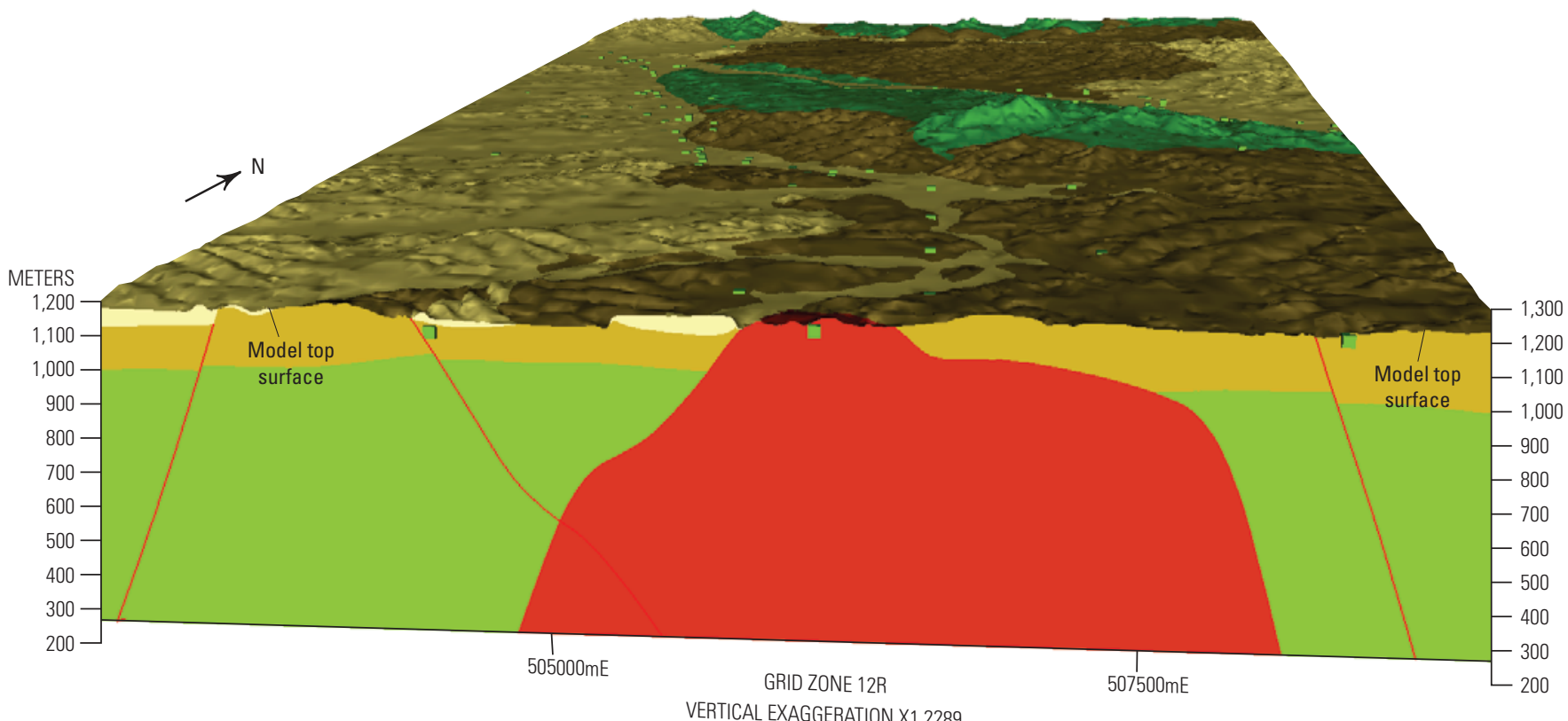

Base from U.S. Geological Survey National Elevation Database, 10 meter DEM Universal Transverse Mercator projection, zone 12, meters North American Datum of 1983 (NAD 83)

\section{EXPLANATION}

Upper hydrogeologic unit

Late Miocene to Holocene surficial deposits

Middle hydrogeologic unit

Miocene Nogales Formation

Lower hydrogeologic unit

Upper Cretaceous diorite stock

Jurassic, Cretaceous, and Tertiary (Oligocene) rocks

Fault where projects out of model area

$\checkmark \quad \mathrm{X}, \mathrm{Y}, \mathrm{Z}$ coordinates for groundwater elevation data

Figure 25. View to the north along the southern edge of the three-dimensional model, showing $X, Y$, and Z coordinates for groundwater elevation data.

American Datum of 1983, zone 12 in meters, and $\mathrm{Z}$ values are elevation in meters above sea level, using North American Vertical Datum of 1988. The EarthVision model required these surfaces to span the entire range of the model. Therefore, when data are limited in spatial extent, control points based on geologic inference are added to the scattered dataset to constrain the surface shape, so it conforms to a particular conceptual geologic model. There are two types of surfaces: "layer" surfaces and "fault" surfaces. Layer surfaces form the boundaries between hydrogeologic unit volumes, and they have a specified order of precedence to resolve and validate surface intersections. Many of the hydrogeologic unit volumes in the model are offset by the fault surfaces, which are typically subvertical in this 3D model, and they split hydrogeologic units into individual fault blocks. Each fault splits a unit into two blocks, and this routine continues if additional faults are added. For example, the first fault surface separates the 3D model into two blocks, and the next fault separates one of those blocks into two additional blocks, and so on. For more information, see http://www.dgi.com.

The construction of the 3D model started with extrapolating surface hydrogeologic unit contacts and faults from the geologic map of Page and others (2016b). To produce the needed model surfaces, hydrogeologic unit and fault surfaces were interpolated and projected into the subsurface based on the dip and trends from the mapped surfaces in outcrop. Extrapolating these data produced scattered data (X, Y, and Z coordinates) that were incorporated into the 3D model. The modeled surfaces created were derived using the software's native minimum surface-tension gridding algorithm. The gridded surfaces were generated in two stages: an initial grid estimate, followed by biharmonic iterations. The top of basement was the first and lowest hydrogeologic unit surface modeled, and the surface was originally defined by scattered data points derived from the geologic cross sections of Page and others (2016b). After the top of basement was defined from the cross sections, the surface was further constrained by incorporating 
additional scattered data points based on geophysical data, which included data from the depth to basement map (fig. 23). The next hydrogeologic unit surface modeled included the top of the Miocene Nogales Formation; this surface was modeled similarly to the surface at the top of basement, and was defined by scattered data derived from a combination of the cross sections of Page and others (2016b) and geophysical data including transient electromagnetic data. Once the final grid estimate was complete, all the grid nodes were reevaluated by a biharmonic cubic-spline function through a number of iterations. To assure grid nodes still adhere to the data, data were brought back into the calculations using a data feedback algorithm for each iteration. Quality control was conducted using two-dimensional and 3D analysis of all geologic and geophysical datasets and interpolated surfaces to ensure visual consistency at the 1:24,000 scale. Greater details of the gridding algorithms are beyond the scope of this report; additional information is available from Dynamic Graphics, Inc., http://www.dgi.com.

Areas of the 3D model where the hydrogeologic unit surfaces are well constrained include within, and adjacent to the uplifted Mount Benedict horst block, where contacts between basement, members of the Nogales Formation, and the late Miocene to Holocene surficial deposits are exposed at, or near the surface (Page and others, 2016b). The contact between basement and the Nogales Formation within the horst block is exposed just to the south of Mount Benedict (fig. 2). On the west side of the horst block, contacts between members of the Nogales Formation and the late Miocene to Holocene surficial deposits are exposed in the southern part of the area, along Nogales Wash and the Grand Avenue fault (fig. 2), and thicknesses of those units are known, allowing for accurate estimation for the depth to basement. On the northeast side of the horst block, the Nogales Formation is widely exposed at the surface along the Mount Benedict fault (fig. 2), and the contact between basement (Oligocene Grosvenor Hills Volcanics) and the Nogales Formation is exposed along the southernmost Grosvenor Hills, in the northern part of the study area (figs. 2 and 3 ). In addition, contacts between the Nogales Formation and the late Miocene to Holocene surficial deposits are exposed in the Guevavi Canyon area and along Sonoita Creek (fig. 2). Hydrogeologic unit contacts are less certain in the western portion of the model area, where late Miocene to Holocene surficial deposits are thicker and conceal the Nogales Formation and basement rocks near the western basin margin.

The 3D model includes only the primary faults that likely affect groundwater flow; splay faults and small isolated faults were excluded. Dips of faults were assigned from surface exposures where possible, and concealed faults were assigned typical values based on data from geologic maps, which locally extend over the upper Santa Cruz Basin (Simons, 1974; Drewes, 1980; and Page and others, 2016b). Faults in the 3D model are predominantly high-angle normal faults, and most faults in surface outcrops in the model area were observed to dip about $70^{\circ}$ (Page and others, 2016b).
Displacement values for most modeled faults ranged from several to tens of meters, and maximum displacements of 300 to $500 \mathrm{~m}$ were modeled along parts of the Grand Avenue and Mount Benedict faults, based on interpretations from Page and others (2016b). Faults were modeled in the following priority: the first faults added crossed the entire 3D-model area (for example, the Mount Benedict fault) and are the primary faults in the $3 \mathrm{D}$ model; then faults that terminated on the primary faults and continued through the model area were modeled; finally all secondary, less continuous faults were modeled.

The Upper Cretaceous diorite stock at the southern edge of the 3D model was constructed by adding scattered data points arranged in a series of stacked concentric polygons, and the subsurface body shape was defined based on the interpretation of geophysical data. The stacked polygons were built as a 3D object and scaled to the model, and then the surface of the intrusion was added to the model as an unconformity.

The resultant 3D model reflects interpretations derived through consensus of the authors, as constrained by the data during the modeling process. All data and interpretations were evaluated for accuracy, consistency, and quality, using two- and three-dimensional visual analyses of all the datasets. This process of model construction resulted in a better understanding of the geology and structure within the upper Santa Cruz Basin.

\section{Conclusions}

The EarthVision model presented in this report extends over the Rio Rico and Nogales 7.5' quadrangles, upper Santa Cruz Basin, southern Arizona. The 3D model is based on the integration and synthesis of geologic information including detailed geologic maps and cross sections, detailed stratigraphic and lithologic description of stratigraphic units pertinent to hydrogeology, and geophysical data including aeromagnetic, gravity, and transient electromagnetic data, and hydrologic data from shallow water wells. Subsurface data, such as deep drill holes, are sparse in the 3D-model area, therefore much of the subsurface geology presented in the report is based on mapped surface geology, combined with geophysical modeling. The 3D model is intended to be used as an interactive viewer in 3D space, to investigate the geometry and hydrogeologic framework of the Miocene to Holocene aquifers, and underlying basement confining units, and faults that intersect these units and may affect groundwater flow.

The 3D model consists of three hydrogeologic units, including a lower basement confining unit, which includes Jurassic monzonite, Cretaceous sedimentary, volcanic and plutonic rocks, and Tertiary (Paleocene and Oligocene) volcanic and plutonic rocks. The middle unit consists entirely of the Miocene Nogales Formation, which consists primarily of volcaniclastic sandstone, conglomerate, siltstone, and claystone. The upper hydrogeologic unit includes late Miocene to early Pleistocene basin fill and Quaternary alluvium combined. 
Only the major faults that likely affect groundwater flow in the basin were modeled. Some of the faults are exposed at the surface, exposing the Jurassic basement as a central core (horst block) within the model area. The Mount Benedict fault, the primary fault modeled, extends across the entire model area, and is not cut by other faults.

\section{References Cited}

Arizona Department of Water Resources [ADWR], 2015, Arizona Department of Water Resources Groundwater Site Inventory (GWSI) database, accessed May 2015 at https://gisweb.azwater.gov/waterresourcedata/gwsi.aspx.

Blakely, R.J., and Simpson, R.W., 1986, Approximating edges of source bodies from magnetic or gravity anomalies: Geophysics, v. 51, no. 7, p. 1494-1498.

Bultman, M.W., 2015, Detailed interpretation of aeromagnetic data from the Patagonia Mountains area, southeastern Arizona: U.S. Geological Survey Scientific Investigations Report 2015-5029, 25 p., accessed April 3, 2018, at https://doi.org/10.3133/sir20155029.

Bultman, M.W., and Page, W.R., 2016, Basement morphology and structure, upper Santa Cruz Basin, south-central Arizona, with transient electromagnetic survey data: U.S. Geological Survey Open-File Report 2016-1152, 49 p., 2 pls., https://doi.org/10.3133/ofr20161152.

Casto, D.W., 2001, Calculating depths to shallow magnetic sources using aeromagnetic data from the Tucson basin: U.S. Geological Survey Open-File Report 2001-505, 231 p.

Clear Creek Associates, 2011, Hydrogeologic investigations of the Santa Cruz micro basins, Nogales, Arizona: prepared for the City of Nogales Utilities Department, May 2011, 21 p.

Cosca, M.A., Page, W.R., Gray, F., Lee, J., Menges, C., and Bultman, M.W., 2013, ${ }^{40} \mathrm{Ar}{ }^{39} \mathrm{Ar}$ geochronology of the Oligocene-Miocene Grosvenor Hills volcanics and the Miocene Nogales Formation, upper Santa Cruz Basin, southern Arizona [abs.]: Geological Society of America Abstracts with Programs, v. 45, no. 7, p. 129.

Culberston, Chris, Lytle, W.E., McMillan, M.M., Sternberg, B.K., and Witheres, K.B., 2010, Transient electromagnetic investigation of microbasin morphology along the Santa Cruz River, Nogales, Arizona: Geophysics Field Camp, May 11, 2010, University of Arizona, 117 p.

Drewes, Harald, 1968, New and revised stratigraphic names in the Santa Rita Mountains of southeastern Arizona, contributions to stratigraphy: U.S. Geological Survey Bulletin, 1274-C, p. C1-C15.
Drewes, Harald, 1971, Geologic map of the Mt. Wrightson quadrangle, southeast of Tucson, Arizona: U.S. Geological Survey Miscellaneous Investigations Map I-614, scale $1: 48,000$.

Drewes, Harald, 1972, Cenozoic rocks of the Santa Rita Mountains, southeast of Tucson, Arizona: U.S. Geological Survey Professional Paper 746, 66 p.

Drewes, Harald, 1980, Tectonic map of southeast Arizona: U.S. Geological Survey Miscellaneous Investigations Map I-1109, scale 1:125,000.

Erwin, Gretchen, 2007, Groundwater flow model of the Santa Cruz active management area micro basins, International boundary to Nogales International Wastewater Treatment Plant, Santa Cruz County, Arizona: Arizona Department of Water Resources Modeling Report No. 15, 143 p.

Gettings, M.E., 2002, An interpretation of the 1996 aeromagnetic data for the Santa Cruz Basin, Tumacacori Mountains, Santa Rita Mountains, and Patagonia Mountains, southcentral Arizona: U.S. Geological Survey Open-File Report 2002-99, $44 \mathrm{p}$.

Gettings, M.E., and Houser, B.B., 1997, Basin geology of the upper Santa Cruz valley, Pima and Santa Cruz counties, southeastern Arizona: U.S. Geological Survey Open-File Report 97-676, 39 p.

Grauch, V.J.S., and Cordell, Lindrith, 1985, Limitations on determining density or magnetic boundaries from the horizontal gradient of gravity or psuedogravity data: Geophysics, v. 52, no. 1 , p. $118-121$.

Hanson, R.T., and Benedict, J.F., 1994, Simulation of groundwater flow and potential land subsidence, upper Santa Cruz Basin, AZ: U.S. Geological Survey Water-Resources Investigations Report 93-4196, 47 p.

Hayes, P.T., 1970, Cretaceous paleogeography of southeastern Arizona and adjacent areas: U.S. Geological Survey Professional Paper, 658-B, p. B1-B42.

Helmick, W.R., 1986, The Santa Cruz River terraces near Tubac, Santa Cruz County, Arizona: Tucson, Ariz., University of Arizona M.S., thesis 96 p.

Mason, and Bota, 2006, Regional groundwater flow model of the Tucson Active Management Area, Tucson, AZSimulation and Application: Arizona Department of Water Resources Modeling Report No. 13, 159 p.

Menges, C.M., 1981, The Sonoita Creek Basin, implications for late Cenozoic tectonic evolution of basin and ranges in southeastern Arizona: Tucson, Ariz., University of Arizona, M.S. thesis, 239 p. 
Menges, C.M., and McFadden, L.D., 1981, Evidence for a latest Miocene to Pliocene transition from basin-and-range tectonic to post tectonic landscape evolution in southeastern Arizona, in Stone, Claudia, and Jenny, J.P., eds., Arizona Geological Society Digest XIII, p. 151-160.

Menges, C.M., and Pearthree, P.A., 1989, Late Cenozoic tectonism in Arizona and its impact on regional landscape evolution, in Jenny, J.P., and Reynolds, S.J., eds., Arizona Geological Society Digest XVII, p. 649-680.

Nabighian, M.N., 1972, The analytic signal of two dimensional magnetic bodies with polygon cross-section-Its properties and use for automated anomaly interpretation: Geophysics, v. 37, p. 507-517.

Nabighian, M.N., 1974, Additional comments on the analytic signal of two dimensional magnetic bodies with polygon cross-section: Geophysics, v. 39, p. 85-92.

Nabighian, M.N., 1984, Towards a three-dimensional automatic interpretation of potential field data via generalized Hilbert transforms-Fundamental relations: Geophysics, v. 49 , p. $780-786$.

Nelson, K., 2007, Groundwater flow model of the Santa Cruz active management area along the effluent-dominated Santa Cruz River, Santa Cruz and Pima Counties, Arizona: Arizona Department of Water Resources, Modeling Report No. 14,117 p.

Page, W.R., 2018, Data release for geologic framework and hydrogeology of the Rio Rico and Nogales 7.5' quadrangles, upper Santa Cruz basin, Arizona, with 3-dimensional hydrogeologic model: U.S. Geological Survey data release, http:// doi.org/10.5066/F7QJ7GHT.

Page, W.R., Gray, F., Bultman, M.W., and Menges, C.M., 2016a, Hydrogeologic investigations of the Miocene Nogales Formation in the Nogales area, upper Santa Cruz Basin: U.S. Geological Survey Scientific Investigations Report 2016-5087, 31 p., accessed April 3, 2018, at https://doi.org/10.3133/sir20165087.

Page, W.R., Menges, C.M., Gray, Floyd, Berry, M.E., Bultman, M.W., Cosca, M.A., and VanSistine, D.P., 2016b, Geologic map of the Rio Rico and Nogales 7.5' quadrangles, Santa Cruz County, Arizona: U.S. Geological Survey Scientific Investigations Map 3354, 32 p. pamphlet, 2 sheets, scale 1:24,000, accessed April 3, 2018, at https://doi.org/10.3133/sim3354.
Phillips, J.D., 2007, Geosoft executables (GX's) developed by the U.S. Geological Survey, version 2.0, with notes on GX development from Fortran code: U.S. Geological Survey Open-File Report 2007-1355, 111 p.

Simons, F.S., 1974, Geologic map and sections of the Nogales and Lochiel quadrangles, Santa Cruz County, Arizona: U.S. Geological Survey Miscellaneous Investigation Series Map I-762, scale 1:48,000, 9 p., pamphlet.

Sweeney, R.E., and Hill, P.L., 2001, Arizona aeromagnetic and gravity maps and data-A Web site for distribution of data, U.S. Geological Survey Open-File Report 2001-81, accessed 2015, at https://pubs.er.usgs.gov/publication/ ofr0181.

Thompson, D.T., 1982, EULDPH—A new technique for making computer-assisted depth estimates from magnetic data: Geophysics, v. 47, p. 31-37.

University of Texas at El Paso, 2013, Gravity database of the U.S., accessed April 3, 2018, at http://research.utep.edu/ default.aspx?tabid $=37229$.

U.S. Department of Agriculture Natural Resources Conservation Service, 2008, Soil Survey Geographic (SSURGO) database for Santa Cruz and parts of Cochise and Pima Counties, Arizona: U.S. Department of Agriculture Natural Resource Conservation Service, az667, accessed October 21, 2010, at http://websoilsurvey.nrcs.usda.gov/.

Vallée, M.A., and Smith, R.S., 2007, Comparison of fixedwing airborne electromagnetic 1D inversion methods, accessed April 3, 2018, at http://www.dmec.ca/ex07-dvd/ E07/posters.html.

Wolfgram, P., and Karlik, G., 1995, Conductivity-depth transform of GEOTEM data: Exploration Geophysics, v. 26, p. $179-185$.

Youberg, A., and Helmick, W.R., 2001, Surficial geologic maps and geologic hazards of the Amado-Tubac area, Santa Cruz and southern Pima Counties, Arizona: Arizona Geological Survey Digital Map 13, scale 1:24,000. 
Publishing support provided by the Science Publishing Network,

Denver and Pembroke Publishing Service Centers

For more information concerning the research in this report, contact the

Center Director,

USGS Geosciences and Environmental Change

Science Center

Box 25046, Mail Stop 980

Denver, CO 80225

(303) 236-5344

Or visit the Geosciences and Environmental Change Science Center website at https://www.usgs.gov/centers/gecsc/ 


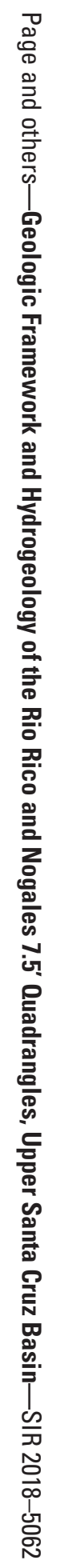

